\title{
Genome
}

\section{Functional analysis of co-expression networks of zebrafish ace 2 reveals enrichment of pathways associated with development and disease.}

\begin{tabular}{|r|l|}
\hline Journal: & Genome \\
\hline Manuscript ID & gen-2021-0033.R1 \\
\hline Manuscript Type: & Article \\
\hline Date Submitted by the & $10-$ Sep-2021 \\
\hline $\begin{aligned} \text { Complete List of Authors: } \\
\text { Keskus, Ayse Gokce; Bilkent Universitesi, } \\
\text { Tombaz, Melike; Bilkent Universitesi } \\
\text { Arici, Burcin Irem; Bilkent Universitesi } \\
\text { Dincaslan, Fatma; Bilkent Universitesi } \\
\text { Nabi, Afshan; Sabanci University } \\
\text { Shehwana, Huma; National University of Medical Sciences } \\
\text { Konu, Ozlen; Bilkent University, Molecular Biology and Genetics }\end{aligned}$ \\
\hline $\begin{array}{r}\text { Is the invited manuscript for } \\
\text { consideration in a Special } \\
\text { Issue? : }\end{array}$ & $\begin{array}{l}\text { Not applicable (regular submission) } \\
\text { zebrafish, ace2, transciptome, network analysis, meta-analysis }\end{array}$ \\
\hline
\end{tabular}

\section{SCHOLARONE" Manuscripts}


1 Functional analysis of co-expression networks of zebrafish ace2 reveals enrichment of

2 pathways associated with development and disease.

3 Ayse Gokce Keskus ${ }^{1}$, Melike Tombaz², Burcin I. Arici², Fatma B. Dincaslan², Afshan Nabi ${ }^{2,3}$,

4 Huma Shehwana ${ }^{2,4}$, Ozlen Konu'1,2,5

$5 \quad{ }^{1}$ Interdisciplinary Program in Neuroscience, Bilkent University, Ankara, Turkey.

62 Department of Molecular Biology and Genetics, Bilkent University, Ankara, Turkey.

$7 \quad{ }^{3}$ Faculty of Engineering and Natural Sciences, Sabancı University, Istanbul, Turkey

$8{ }^{4}$ Department of Biological Sciences, National University of Medical Sciences, Rawalpindi,

9 Pakistan

$10{ }^{5}$ UNAM-Institute of Materials Science and Nanotechnology, Bilkent University, Ankara, Turkey.

11 *Corresponding Author: Ozlen Konu, konu@fen.bilkent.edu.tr

\section{Abstract}

13 Human Angiotensin I Converting Enzyme 2 (ACE2) plays essential roles in blood pressure

14 regulation and SARS-CoV-2 entry. ACE2 has a highly conserved, one-to-one ortholog, called

15 ace2, in zebrafish, which is an important model for human diseases. However, zebrafish ace2

16 expression profile has not yet been studied during early development, between genders, across

17 different genotypes, or in disease. Moreover, a network-based meta-analysis for the extraction of

18 functionally enriched pathways associated with differential ace2 expression is lacking in the

19 literature. Herein, we first identified significant development-, tissue-, genotype- and gender-

20 specific modulations in ace2 expression via meta-analysis of zebrafish Affymetrix transcriptomics

21 datasets $\left(n_{\text {datasets }}=107\right)$; and the correlation analysis of ace2 meta-differential expression profile

22 revealed distinct positively and negatively correlated local functionally enriched gene networks.

23 Moreover, we demonstrated that ace2 expression was significantly modulated under different 
24 physiological and pathological conditions related to development, tissue, gender, diet, infection,

25 and inflammation using additional RNAseq datasets. Our findings implicate a novel translational

26 role for zebrafish ace 2 in organ differentiation and pathologies observed in the intestines and liver.

27 Keywords: zebrafish, ace2, transcriptome, network analysis, meta-analysis

\section{INTRODUCTION}

29 ACE2 and ACE, involved in angiotensin conversion, are integral elements of renin-angiotensin

30 signaling (RAS) in multiple tissues. Recent studies have shown that RAS is not only present in

31 kidney or adrenal glands but also functional in other tissues with significant roles in multiple

32 pathologies, including cancer (Cheng and Liu, 2019, Nehme et al., 2019, Pinter and Jain, 2017,

33 Rasha et al., 2019). The role of ACE2 and ACE in the regulation of hypertension is well known

34 (Hamming et al., 2007), and recently ACE2 has also become the focus of intense research due

35 to its function as a receptor of SARS-CoV-2 entry in COVID-19 (Ziegler et al., 2020). In addition,

36 ACE2 expression is tissue-specific; for example, recent findings from single-cell RNA-seq studies

37 show that $A C E 2$ is highly expressed in type II pneumocytes and intestinal enterocytes, in which

38 SARS-CoV-2 can replicate (Ziegler et al., 2020).

39 Apart from mammalian models, recently, zebrafish has been used to study ace2 expression or

40 function. Zebrafish ace2 is highly conserved in sequence and structure to its mammalian

41 counterparts and exists as the only copy in zebrafish with a duplicated genome (Chou et al.,

42 2006). Furthermore, a recent study, phylogenetically comparing genes co-expressed with ace2

43 based on zebrafish single-cell RNA-seq tissue data, has revealed RAS signaling is also

44 conserved between humans and zebrafish (Postlethwait et al., 2021). However, to our knowledge,

45 there is no study investigating the changes in ace2 expression over zebrafish embryonic and

46 larval developmental stages, between genders, and in the different whole adult tissues as well as

47 across different genotypes, treatments, or pathologies. Accordingly, a meta-analysis of differential 
expression of zebrafish ace2, performed across public datasets, may reveal important functionally enriched networks (Shehwana and Konu, 2019).

50 Co-expression analysis is a widely used and effective method based on the guilt-by-association 51 principle to identify the regulatory mechanisms of transcription under certain conditions. Several

52 methods have been proposed to perform co-expression analysis, i.e., effect size combination, 53 rank combination, p-value combination, and random sampling (Evangelou and loannidis, 2013,

54 Gur-Dedeoglu et al., 2008, Kolde et al., 2012, Tseng et al., 2012). Since traditional co-expression 55 analysis methods are based on using the expression values from individual samples, preprocessing steps may be required to remove batch effects between datasets. However, data

57 merging with the increasing number of datasets may not be optimal (Cheung and Vijayakumar, 58 2016); and when combining a heterogeneous set of datasets requires different approaches (Ter 59 Veer et al., 2019). Recent network-based methods have proposed combining the individual co60 expression network of each dataset, calculated separately, yet these are computationally 61 expensive for a large collection of datasets (Ter Veer et al., 2019). A simpler and widely used 62 methodology is to use or compare the logFC values (as the mean expression value normalized 63 to internal control) obtained for each dataset that may come from numerous conditions; this 64 methodology has been used in different contexts, including miRNA target prediction, 65 toxicogenomic pattern, and compound similarity matrix (Kramer et al., 2020, Yoon et al., 2019, 66 Zhou et al., 2018, Cheng, 2013). Here, we combined these two methods, i.e., logFC comparison 67 and co-expression network, and performed a pairwise correlation analysis between ace2 and 68 other genes using logFC values obtained from re-analysis (limma) of public zebrafish Affymetrix 69 datasets (GEO), followed by network enrichment.

70 Briefly, we hypothesized that significantly enriched functional local networks extracted based on

71 the differential expression profile of ace2 across divergent contexts can provide a better 72 understanding of zebrafish ace2 function. Using the wealth of transcriptomics data present in the 
73 zebrafish literature, we aimed to identify the development-, tissue, gender-, and genotype-specific

74 differences in ace 2 expression and extract its co-differentially expressed transcriptome in

75 zebrafish using available datasets. We also investigated whether ace2 was tissue-specific and

76 found it was expressed the most in intestines followed by liver, although highly variably. We then

77 performed comparisons between relevant datasets using local network signatures (STRING) of

78 genes co-expressed with ace2; this helped prioritize the positively and negatively ranked local

79 functional pathways with which ace2 was associated in development, intestinal differentiation,

80 and variable liver expression. Using additional datasets, we showed that zebrafish ace2 was also

81 modulated in the different liver and intestinal pathologies, demonstrating its translational

82 importance.

\section{METHODS}

\section{Co-differential expression analysis using Affymetrix Zebrafish Chip datasets (GPL1319)}

85 Raw CEL files for all available datasets for GPL1319 were obtained from the NCBI GEO database

86 (Fig. S1) (Barrett et al., 2013). Groups containing at least two samples were used for comparisons,

87 and datasets with no comparable groups were excluded ( $\left.\mathrm{n}_{\text {datasets }}=107\right)$. Normalization of CEL

88 files for each study was performed separately, using rma in affy package (Gautier et al., 2004).

89 From 107 datasets, 344 two-group comparisons were manually generated with the following rules:

90 1. each experimental group was compared to its corresponding control group; 2. experimental

91 groups with double mutation or morpholino treatment were compared to each of the single

92 mutation/morphant group; 3. only control (or wild type) groups from different tissues,

93 developmental time points or gender were compared with each other; 4 . for time series, all other

94 groups were compared to the group with the earliest time point only. Differential expression

95 analysis using limma was conducted for each of the manually generated two-group comparisons

96 with the normalized datasets (Ritchie et al., 2015). A matrix of logFC values, $X_{\text {logFC, was obtained }}$

97 where each row corresponded to a gene and each column one of the limma comparisons. The 
98 average logFC values for each gene were calculated across 344 comparisons whose distribution

99 was plotted as a histogram. A Pearson correlation coefficient $\left(r_{\text {ace2-logFC }}\right)$ was then calculated

100 between ace2 and every other gene found in $\mathrm{X}_{\text {logFC. }}$ Furthermore, $r_{\text {ace2-logFC }}$ values were used to

101 identify STRING enriched local networks, i.e., small protein-protein interaction networks with 5 to

102200 members, obtained through hierarchical clustering of the human protein-protein network and

103 named according to the consensus annotations of proteins found in subnetworks (Szklarczyk et

104 al., 2019). In addition, the limma comparisons in which ace2 was differentially expressed were

105 identified upon setting the FDR and logFC thresholds stringently (adj. p-value $<0.05$ and $106 \operatorname{abs}(\log \mathrm{FC})>0.5)$.

\section{Identification of tissue-specific expression patterns of ace2 in zebrafish adult tissues}

108 Raw data for selected tissue datasets (Table S1) were obtained from SRA (Chen et al., 2020a) 109 and analyzed using Seven Bridges Cancer Genomics Cloud (CGC;

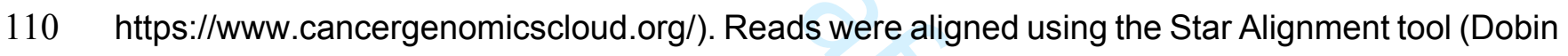
111 et al., 2013). HTSeq tool (Anders et al., 2015) was used to retrieve the count data. Raw count 112 data were normalized using the RPKM function from the edgeR package in R (McCarthy et al., 113 2012). Samples from the same tissue and from different datasets were visualized by plotting the 114 scores from the first two dimensions of Principal Component Analysis (PCA) as well as 115 hierarchical clustering. Tau was used as the tissue specificity index as described previously 116 (Kryuchkova-Mostacci and Robinson-Rechavi, 2017).

117 Dataset collection for investigating sexual dimorphism, and intestinal and liver 118 development and disease

119 Zebrafish transcriptomics datasets selected from NCBI GEO or Expression Atlas (Papatheodorou 120 et al., 2020) according to their relevance to sexual dimorphism, liver and gut development, and 121 disease/treatments were summarized in Table S2. Series matrix files for four datasets of 
122 GPL14664 (GSE113241 (Alvarez-Rodriguez et al., 2018); GSE112272 (Jia et al., 2019);

123 GSE73233 (Forn-Cuni et al., 2017); and GSE100583 (Holden and Brown, 2018)) and RPKM

124 normalized data of GSE74244 (Aramillo Irizar et al., 2018), GSE118076 (San et al., 2018), and

125 GSE24616 (Domazet-Loso and Tautz, 2010) were obtained from GEO and used for statistical

126 analysis after logarithmic (log2) transformation. The expression of ace2 in the E-ERAD-475

127 dataset was obtained from Expression Atlas (White et al., 2017). ANOVA followed by multiple test

128 correction (Tukey's HSD) was used for statistical analyses as indicated in the figure legends. Raw

129 count data of GSE82200 (Koch et al., 2018), GSE83195 (Schall et al., 2017) and GSE123439

130 (Chen et al., 2020b) were obtained from NCBI GEO; Deseq2 package was used for the differential

131 gene expression analysis; and Regularized log (Rlog) normalized expression values were used

132 in visualization (Love et al., 2014).

\section{Condition-specific co-expression analysis}

134 For the generation of co-expression network of ace2, a Pearson's correlation coefficient, called

$135 r_{a c e 2}$, was calculated between ace2 and each gene based on the log2 transformed expression

136 values, generating a vector of $r_{a c e 2}$ values for each comparison studied, namely, a) larval

137 development, using GSE24616 (2 dpf-8 dpf) and GSE38575 (EtOH treated samples only; 2dpf -

138 7dpf) datasets; b) intestinal expression, using GSE35889 and GSE12189 (GFP+ samples only);

139 and c) expression in liver, using GSE74244 (liver samples only) and GSE100583, separately (Fig.

140 S2, Table S2). The $r_{a c e 2}$ value with the minimum $p$-value was selected for multiple probesets

141 having the same Ensembl ID.

\section{Comparative Network Enrichment Analysis (CNEA)}

143 Ensembl IDs and each of the condition-specific $r_{\text {ace2 }}$ values was used to identify local network 144 clusters using STRING enrichment analysis (Szklarczyk et al., 2015). After obtaining enrichment 145 results for each dataset, the Comparative Network Enrichment Analysis (CNEA) of STRING local 
146 networks was performed to identify consistently enriched local networks common in both datasets

147 and visualized via scatter plots $(F D R<0.01)$. Enriched local networks with the largest gene set

148 were selected in the presence of multiple local networks with the same name. A local network

149 interaction graph was then generated using networks significantly (FDR <0.01) enriched in both

150 datasets where nodes represent local networks and edges, the number of shared genes between

151 local networks. The generated graph was then clustered in Cytoscape using the Markov Cluster

152 Algorithm (MCL) (Shannon et al., 2003). Selected local networks were visualized in detail, where

153 each node on the specific STRING local network data referred to a gene and was colored

154 according to its $r_{a c e 2}$, i.e., the correlation with ace2 expression. In addition, a GO term enrichment

155 analysis was performed for liver datasets using the clusterprofiler package in R (Yu et al., 2012).

\section{RESULTS}

\section{Re-analysis of zebrafish GPL1319 datasets reveal conditions in which ace2 expression is}

158 significantly modulated

159 Upon re-analysis of publicly available datasets from the GPL1319 platform ( $\mathrm{n}=107$ with 344

160 pairwise group comparisons), ace2 expression was found differentially expressed in 19 pairwise

161 group comparisons from 11 different datasets relevant to sexual dimorphism, estrogen signaling,

162 embryogenesis, and liver and gut development (Table 1) (Froehlicher et al., 2009, Heiden et al.,

163 2008, Hu et al., 2013, Jacob et al., 2015, Maclnnes et al., 2008, Rogers et al., 2011, Small et al.,

164 2009, Soni et al., 2013, Stuckenholz et al., 2009, Thakur et al., 2014, Okuda et al., 2010). The

$165 \log F C$ matrix for all zebrafish genes across 344 comparisons was generated, and row (i.e., gene)

166 mean and coefficient of variation (CV) values were found to be distributed symmetrically around

1670 (Fig. S3A-B). The co-differential expression vector of ace2, $r_{\text {ace2-logFC }}$, was used to obtain

168 STRING local network clusters, which revealed that genes positively correlated with ace2 were

169 enriched in carboxypeptidase activity (Figure 1A), intestinal hexose absorption, villin and keratin,

170 and fibrin clot formation associated sub-groups (Fig. S4A) whereas those negatively correlated 
171 belonged to cilium assembly (Figure 1B), microtubule organization pathways, and chromatin-

172 modifying enzymes (Fig. S1A). Ten genes were represented in the GPL1319 platform out of 28

173 RAS pathway genes (Postlethwait et al., 2021), and eight of them were found to be positively

174 correlated with ace2, with a correlation coefficient ranging from 0.46 to 0.85 .

175 Table 1: GPL1319 datasets in which zebrafish ace2 with a probe set ID "Dr.20290.1.A1_at" was

176 significantly differentially expressed (FDR (adj. p-value) $<0.05$ and abs(logFC) $>0.5)$. MCLR,

177 MPNST, TCDD, LNA, GIT, refer to microcystin-LR, malignant peripheral nerve sheath tumor,

178 2,3,7,8-Tetrachlorodibenzo-p-dioxin, locked nucleic acid, and gastrointestinal tract.

\begin{tabular}{|l|l|l|l|l|}
\hline Dataset ID & logFC & $\mathbf{p}$-value & adj. p-value & Comparison \\
\hline GSE14979 & -3.92 & $8.7 \mathrm{E}-06$ & $2.1 \mathrm{E}-04$ & Ovary vs Female Body \\
\hline GSE14979 & -3.88 & $1.0 \mathrm{E}-06$ & $1.5 \mathrm{E}-05$ & Testis vs Male Body \\
\hline GSE13158 & -3.77 & $5.7 \mathrm{E}-16$ & $2.1 \mathrm{E}-13$ & $50 \mathrm{uM}$ ERbeta2 vs Control morpholino \\
\hline GSE17711 & -1.86 & $4.8 \mathrm{E}-06$ & $1.1 \mathrm{E}-03$ & cdipt Mutant vs Wild type \\
\hline GSE55339 & -1.43 & $8.5 \mathrm{E}-05$ & $1.2 \mathrm{E}-02$ & uhrf1 Mutant vs Wild type \\
\hline GSE12214 & -1.10 & $3.0 \mathrm{E}-04$ & $4.3 \mathrm{E}-03$ & $1000 u g$ MCLR vs Control ethanol \\
\hline GSE11493 & -1.06 & $1.6 \mathrm{E}-03$ & $1.1 \mathrm{E}-02$ & MPNST (p53mut) vs Seminoma \\
\hline GSE14979 & -0.90 & $1.1 \mathrm{E}-02$ & $2.0 \mathrm{E}-02$ & Ovary vs Testis \\
\hline GSE4859 & -0.81 & $8.3 \mathrm{E}-05$ & $5.1 \mathrm{E}-03$ & Whole ovary 100ppb TCDD vs Whole ovary control \\
\hline GSE12214 & -0.80 & $4.1 \mathrm{E}-03$ & $4.2 \mathrm{E}-02$ & $100 u g$ MCLR vs Control ethanol \\
\hline GSE32360 & -0.64 & $2.2 \mathrm{E}-02$ & $3.6 \mathrm{E}-02$ & 24 hpf mock LNA vs 1 hpf mock LNA \\
\hline
\end{tabular}




\begin{tabular}{|l|l|l|l|l|}
\hline GSE18830 & -0.63 & $2.1 \mathrm{E}-03$ & $6.0 \mathrm{E}-03$ & $75 \%$ Epiboly vs 30\% Epiboly \\
\hline GSE18830 & -0.56 & $1.0 \mathrm{E}-03$ & $2.4 \mathrm{E}-03$ & Tail Bud vs 30\% Epiboly \\
\hline GSE12189 & 2.92 & $7.9 \mathrm{E}-03$ & $4.8 \mathrm{E}-02$ & 6 dpf (GIT) vs 2 dpf (GIT) \\
\hline GSE12189 & 3.05 & $9.6 \mathrm{E}-06$ & $5.4 \mathrm{E}-04$ & 6 dpf (not-GIT) vs 2 dpf (not-GIT) \\
\hline GSE12189 & 3.85 & $4.5 \mathrm{E}-06$ & $3.2 \mathrm{E}-04$ & 3 dpf (GIT) vs 3 dpf (not-GIT) \\
\hline GSE12189 & 3.95 & $9.0 \mathrm{E}-06$ & $5.6 \mathrm{E}-03$ & 3 dpf (GIT) vs 2 dpf (GIT) \\
\hline GSE12189 & 4.68 & $5.3 \mathrm{E}-04$ & $1.2 \mathrm{E}-02$ & 4 dpf (GIT) vs 2 dpf (GIT) \\
\hline GSE35889 & 7.58 & $5.7 \mathrm{E}-07$ & $3.6 \mathrm{E}-04$ & $c d x 1 b$ Transgenic vs Wild type \\
\hline
\end{tabular}

181 Analysis of GPL1319 datasets revealed ace2 expression decreased throughout gastrulation 182 (GSE18830, GSE32360; Table1), which was supported by re-analysis of GSE24616 (Figure 2A) 183 and E-ERAD-475 (Fig. S1B). In addition, we found ace2 was lowly expressed in embryogenesis 184 and started increasing at $3 \mathrm{dpf}$ and thereafter until $4 \mathrm{dpf}$, after which it was steadily expressed at 185 high levels (Figure 2A, Fig. S4B). Analysis of yet another dataset (GSE38575) supported this 186 finding of a significant increase in ace2 expression after $3 \mathrm{dpf}$ in zebrafish (Figure 2B). The 187 STRING local network enrichment scores based on $r_{a c e 2}$ values (between expression profile of 188 ace2 and that of every other gene), obtained separately for GSE24616 (2dpf - 8dpf) and 189 GSE38575 (untreated; 2dpf - 7dpf) zebrafish embryonic development datasets, were significantly 190 correlated with each other $(r=0.963$, $p$-value $=7.63 \mathrm{e}-127$; Figure $2 \mathrm{~A}-\mathrm{C})$. Network clustering 191 helped us define pathways modulated at the time of ace2 induction during the development of 192 early zebrafish larvae. Accordingly, networks enriched with genes positively correlated with ace2 
193 included pathways related to intestinal hexose absorption, vitamin D metabolism,

194 carboxypeptidases, interleukin signaling, phenylalanine/tyrosine catabolism, peptide ligand

195 binding, and dopamine receptors, phototransduction, and common fibrin clot/fibrinolysis (Figure

1963 , Fig. S5). On the other hand, networks enriched with negatively correlated genes included terms

197 such as chromosome segregation, cilium assembly, DNA double-strand break and replication,

198 homeobox, alternative splicing, and endothelial cell proliferation (Figure 3, Fig. S6, Table S3). We

199 then generated graphs with positively and negatively enriched networks separately in which the

200 edge weights representing the number of genes common in both networks to obtain a more

201 comprehensive view of the ace2's functions. Here we found that interleukin-20, $-6,-21$, and -35

202 signaling networks formed a network, and some of the genes involved in vitamin D metabolism

203 along with SLC mediated transmembrane transport networks were also enriched (Figure 4).

204 Networks relevant with chromatin segregation clustered together with the checkpoint associated

205 networks, while cilium assembly and microtubule organization formed separate networks as in

206 the case of DNA damage response associated networks (Figure 5).

\section{7 ace2 expression in zebrafish is sexually dimorphic and tissue-specific}

208 One of the most prominent findings of the GPL1319 dataset meta-analysis was the identification 209 of sexual dimorphism in zebrafish ace2 expression, as shown in Table 1 (GSE14979; Table 1).

210 Interestingly, gonads had lower ace2 expression when compared with the rest of the body 211 regardless of sex, while testis had relatively higher ace2 levels than the ovary (GSE14979; Fig.

212 S7A). Moreover, ace2 expression decreased in the presence of a morpholino for ERBeta2 (esr2a)

213 (GSE13158; Table 1), previously shown to be essential for female sexual maturation and early

214 follicle generation (Lu et al., 2017, Wu et al., 2020). We then re-analyzed the GSE24616 dataset

215 for ace2 expression in adult zebrafish through time and found ace2 was highly expressed in 216 juveniles and early adulthood (90 dpf) (Figure 6A). Moreover, males exhibited high ace2 217 expression regardless of age while females showed a steady decrease over aging until 9 months 
218 (Figure 6A; adj. p-value <0.0001 (age), adj. p-value <0.0001 (gender), adj. p-value $=0.43$

219 (interaction)); however, after 9 months, ace2 levels were indistinguishable between males and 220 females. Results obtained from another dataset, GSE123439, were consistent with the observed 221 significance of sexual dimorphism in gonads (Fig. S7B). In addition, we interrogated the tissue222 specificity of ace2 using a collated dataset (Methods for details). Samples from the same tissue 223 and/or anatomically related organs were clustered together in PCA and hierarchical clustering 224 (Fig. S8). We found that the intestines and liver exhibited relatively high ace2 expression in 225 comparison with the brain, gills, and kidneys in that descending order (Figure 6B). Accordingly, 226 zebrafish ace2 expression was found to have a high tissue specificity index value (Tau) of 0.99 227 (Kryuchkova-Mostacci and Robinson-Rechavi, 2017). ace2 exhibits the highest expression in intestines

229 In accord with the above tissue-specificity analysis, our meta-analysis of GPL1319 datasets also 230 implicated ace2 in intestinal development. Indeed, ace2 expression increased the most in the 231 intestines of the zebrafish overexpression model of $c d x 1 b$, an intestinal differentiation-related 232 transcription factor (GSE35889, Table 1). Moreover, ace2 expression increased in GFP+ 233 gastrointestinal tract (GIT) cells of transgenic (Tg(XIEef1a1:GFP)s854) zebrafish larvae at and 234 after $3 \mathrm{dpf}$ compared to $2 \mathrm{dpf}$ (GSE12189, Table1; Figure 7A) while in GFP- (non-GIT) cells, ace2 235 was significantly upregulated at $6 \mathrm{dpf}$ only. Since ace2 expression also increased in GFP+ cells 236 when compared to GFP- cells at $3 \mathrm{dpf}$ (GSE12189, Table1; Figure 7A), we further performed a 237 comparative network enrichment analysis (Methods for details of CNEA) of STRING local 238 networks between GSE12189 and GSE35889 datasets. Network enrichment scores of the above239 mentioned datasets were highly correlated $(r=0.798, p$-value $=6.49 \mathrm{e}-12$; Figure 7B) 240 strengthening the role of ace2 during intestinal differentiation. The top common networks included 241 those of intestinal hexose absorption, chylomicron assembly, i.e., a key mechanism for lipid 242 transport in the intestines, common pathway of fibrin clot formation and fibrinolysis, fatty acid 
243 degradation, and carboxypeptidases (Figure 7C, Fig. S9). On the other hand, negatively

244 correlated genes were enriched in networks of striated muscle contraction and mRNA splicing

245 (Figure 7C, Fig. S9). Moreover, increases in ace2 expression were steady overtime in late 246 zebrafish larvae with functional intestines (Fig. S10A).

\section{7 ace2 expression is altered with inflammation}

248 We next focused on available disease model datasets of zebrafish for examining changes in ace 2 249 expression in inflammation of the intestines and liver. From an intestinal disease perspective, 250 ace2 was found to be downregulated in the zebrafish model of Short Bowel Syndrome (SBS) (Fig. 251 S10B), which may implicate a possible link between ace2 expression and inflammatory response 252 (Johnson et al., 2018, Mutanen et al., 2019, Schall et al., 2017). We further re-analyzed two other 253 expression datasets associated with different inflammatory stimuli in relationship with the 254 zebrafish digestive system. No significant alteration in ace2 expression was observed in response 255 to bacterial colonization (Conventionalization (CONVD), Exiguobacterium (Exi), or 256 Chryseobacterium (Chrys)), in zebrafish embryos (GSE82200, Figure 8A). However, ace2 257 expression significantly increased with immunosuppression in the myd88 knock-out zebrafish 258 embryos showing significant effects for genotype and treatment with a significant interaction in 259 between these factors (GSE82200; adj. p-value $=4 \mathrm{e}-07$ (Genotype), adj. p-value $=0.03$ (Germ), 260 adj. p-value $=0.03$ (interaction); Figure 8B). On the other hand, ace2 expression decreased in 261 kidney with SVCV infection after pre-treatment with $\beta$-glucan but not with exposure to 262 lipopolysaccharides (LPS) or Polyinosinic:polycytidylic acid (Polyl:C) exposure (GSE113241, adj. 263 p-value $=0.01$ (SVCV), adj. p-value $=0.06$ (pre-treatment), adj. $p$-value $=0.04$ (interaction); 264 Figure 8B). LPS treatment was not effective in the liver, muscle, or kidney, either (Fig. S10C). 
266 Since ace2 exhibited the second highest yet bimodal expression levels in the liver (Figure 6B;

267 Fig. S11A), we performed GO annotation of genes having high or low $r_{a c e 2}$ values, obtained 268 analyzing the GSE74244 dataset (the largest RNA-seq zebrafish cohort for zebrafish adult liver 269 tissue in GEO database). Significant GO biological processes of genes whose expression levels 270 were positively correlated with that of ace 2 were enriched in metabolism, and in particular, that of 271 the lipid (Fig. S11B), whereas those negatively correlated included immune response (Fig. S11C).

272 We also showed that liver expression was not sexually dimorphic and could vary regardless of 273 strain and gender using another dataset (GSE100583, Fig. S12A). Results of GO enrichment 274 analysis of GSE100583 were similar in terms of positively correlated genes, yet cilium 275 organization and establishment of cell polarity were found among significantly negatively 276 correlated pathways (Fig. S12B, C). CNEA of STRING local networks between these two 277 independent datasets (GSE74244 vs. GSE100583) were highly concordant for a subset of 278 pathways (Figure 9A, Fig. S13A) and included networks of genes with positive $r_{\text {ace2 }}$ such as 279 intestinal brush border proteins (villin and keratin) as well as interferon-stimulated genes (ISG15 280 antiviral mechanism), carboxypeptidases, and respiratory electron transport and oxidative 281 phosphorylation (Figure 9A, Fig. S13B). Erythropoietin and hemoglobin network was among those 282 enriched with negative $r_{a c e 2}$ values in both datasets (Figure 9A, Fig. S13B). However, 283 apolipoprotein A/E genes, known to be functional in fat metabolism and immune response, 284 although enriched in both datasets, acted in the opposite direction (Figure 9A).

285 We further investigated ace2 expression in zebrafish under conditions of fasting and refeeding in 286 the liver and found ace2 expression increased when refed after 3 weeks of fasting (Figure 9B) yet 287 it was not altered when given a high carbohydrate diet (GSE8856 (Robison et al., 2008); logFC = 2880.24 , adj. $p$-value $=0.51$ (females) and $\log F C=-0.67$, adj. $p$-value $=0.99$ (males)) or under the 289 condition of overfeeding (GSE48806 (unpublished data); $\log F C=-1.76$, adj. $p$ value $=0.26$ ). In 290 further support of potential involvement of ace2 co-expressed gene network in liver disease, ace2 
291 expression decreased in the zebrafish non-alcoholic fatty liver disease (NAFLD) model

292 (GSE17711; Table 1) and in response to microcystin-LR, previously shown to cause liver damage

293 (GSE11214; Table1, Figure 9C) (Rogers et al., 2011).

\section{Discussion}

295 Zebrafish as a model organism is widely used to understand disease mechanisms due to its high 296 sequence/functional similarity with humans as well as the availability of a wide range of zebrafish 297 genetic models (Gomes and Mostowy, 2020, Logan et al., 2018, Mickiewicz et al., 2019, Willis et 298 al., 2016, Shehwana and Konu, 2019). Conservation and functional similarity of ace2 and the 299 RAS pathway in zebrafish (Postlethwait et al., 2021) make a disease-focused investigation of 300 zebrafish ace2 expression essential, yet this has remained unexplored. Our meta-analysis and/or 301 functional network enrichment approaches with respect to various contexts, including age, 302 gender, tissue specificity, genotype, and disease, make the present study unique and timely.

303 Our meta-analysis has demonstrated that ace2 is expressed at low levels during early larval 304 development yet starts increasing in expression during differentiation of the liver and intestines 305 (Kimmel et al., 1995). Developmental studies in mice report Ace2 expression at E12.5 day with 306 an increasing trend over time in kidneys, lung, brain, and heart (Song et al., 2012), while ACE2 is 307 also expressed in the human intestines, gonads, kidneys, heart, adipose tissue, lung, and liver in 308 accord with its multiorgan functionality (Musavi et al., 2020, Wang et al., 2020). In zebrafish, the 309 ace2 gene is expressed highly in a subcluster of intestinal epithelial cells, where the ace is also 310 expressed (Postlethwait et al., 2021). Herein we have demonstrated that ace2 is tissue311 specifically expressed in zebrafish adult intestines as ACE2 in humans (Musavi et al., 2020). Our 312 analyses also suggest a potential role for intestinal differentiation for ace2, whose expression is 313 higher in the $c d x 1 b$ transgenic strain exhibiting increased intestinal differentiation (Hu et al., 2013).

314 This finding supports that $c d \times 1 b$ could be a transcriptional regulator of ace 2 in zebrafish as $315 C d \times 2 / C D X 2$ is in mice (Chen et al., 2020a) and in humans (Cheng et al., 2008, Flores et al., 2008, 
316 Silberg et al., 2000). Moreover, the fish larvae with a mutation in the uhrf1 gene cause non-

317 functional intestines and also exhibit lower levels of ace2, further supporting a potential role for 318 ace2 in intestinal development (Table 1) (Ganz et al., 2019, Marjoram et al., 2015).

319 Herein, we compared the local enrichment scores between independent datasets (Yildiz et al., 320 2013) to increase confidence in our context-dependent analysis, i.e., ace2 co-expression in 321 intestinal development and liver. Such a comparative analysis has proven to be an effective 322 strategy demonstrating that ace2 expression is a tightly co-expressed component of 323 carboxypeptidases. Interestingly, this is in accord with the reports proposing the serine protease 324 family of genes, which ace2 is part of, as a target for COVID-19 treatment (reviewed in (Vargas 325 et al., 2020, Yao et al., 2020). Other networks we identified included fibrinolysis (positive $r_{\text {ace2 }}$ ), 326 and since COVID-19 severity is associated with dysregulation of clot formation (reviewed in 327 (Coccheri, 2020)), we propose that zebrafish larvae can be used to test the effects of SARS-CoV3282 on the fibrinolysis pathway members with which ace2 is co-expressed during the specific time329 window of intestinal development.

330 Interestingly, several studies have previously reported a higher ACE2 expression in cilia of well331 differentiated epithelial cells compared to undifferentiated cells in humans (Jia et al., 2005, Lee et 332 al., 2020b, Ziegler et al., 2020). ACE2 expression is present in motile cilia in the human airway 333 epithelial cells (Lee et al., 2020a) and also shown to be affected by SARS-CoV infection (Lee et 334 al., 2020b), which causes loss of cilia (Ziegler et al., 2020). Further studies are needed to 335 understand the dynamicity between ace2 expression and cilium assembly. Indeed, the significant 336 changes observed in the ace2 expression levels at the time of intestinal differentiation also 337 provide an effective translational time frame for testing potential drugs affecting intraflagellar 338 transport and the RAS pathway.

339 Consistently, our analyses of $r_{a c e 2}$ in zebrafish have also pointed to the enrichment of respiratory 340 chain-related networks. In support of this, Ace2 knock-out mice have been reported to exhibit 
341 disrupted mitochondrial function in pancreatic islets and skeletal muscle cells (Cao et al., 2019,

342 Shi et al., 2018). Transcriptomic analyses with human cornea, retina and lung datasets propose

343 ACE2 is significantly co-expressed with mitochondrial genes (Yuan et al., 2020). Indeed, Ang II

344 is known to activate NADPH and can stimulate an increase in reactive oxygen species (ROS) in

345 renal cells, while ACE2, as a negative regulator of Ang II, has a protective role against ROS (Gava

346 et al., 2009, Gwathmey et al., 2010, Kim et al., 2012). Ace2 knock-out mice also exhibit increased

347 insulin resistance which can lead to hepatic and oxidative stress (Cao et al., 2014, Gallagher et

348 al., 2008, Gwathmey et al., 2010, Song et al., 2020). The enrichment of ROS-related pathways in

349 our analysis supports the notion that zebrafish can also serve as a model organism to study the

350 potential link between the modulatory role of ace2 in mitochondrial function and disease.

351 Our findings have also indicated the liver as the second-highest ace2 expressing tissue in

352 zebrafish yet with a clear bimodal pattern regardless of age (6 months - 42 months) or gender.

353 This bimodality might have arisen from contamination with other tissues, especially the gut and/or

354 pancreas, and/or the presence of intrinsic or extrinsic factors in relationship with diet,

355 inflammation, or infection. GO enrichment analyses of ace2's positively co-expressed genes

356 revealed the involvement of lipid catabolism as a potential discriminator between the low and high

357 ace2 expressing liver; in partial support of this, our re-analysis shows that ace2 levels decrease

358 in response to microcystin-LR, a common form of cyanotoxin, which causes liver damage and

359 disruption of lipid metabolism (Liu et al., 2014, Woolbright et al., 2017); and in the NAFLD

360 zebrafish model, in accord with mouse data in the literature (Cao et al., 2016, Yang et al., 2020).

361 In our re-analysis, ace2 expression in zebrafish refed liver steadily increases after fasting, aiding

362 in the connection between ace2 expression and diet. Ace2 levels also have been shown to be

363 elevated in high-fat-fed mice and rats (Gupte et al., 2008, Shoemaker et al., 2019, Zhang et al.,

364 2014), but not in the initial response to lipid exposure in zebrafish digestive organs (Zeituni et al.,

365 2016). This suggests that further experiments are needed to identify the time frame the diet can 
366 alter ace2 levels in zebrafish. In addition to altered lipid metabolism, interferon pathway 367 modulation (ISG15 antiviral mechanism network) has arisen as a discriminator of the low and high 368 ace2 expressing liver in zebrafish. The liver, an organ continually subjected to food antigens and 369 pathogens from intestines, can respond to such activators of immune response readily with its 370 residential macrophages (Bleriot and Ginhoux, 2019); and this may result in highly variable 371 interferon activity in the liver (reviewed in (Robinson et al., 2016)). Future studies focusing on 372 embryonic and tissue-specific ace2 knock-out and overexpression models can help understand 373 the role of adaptive and innate immune system challenges in zebrafish liver expression variability.

374 Moreover, a significant decrease identified in ace2 levels in response to vitamin D treatment 375 during early development can be studied further in different contexts, including COVID-19 376 (Benskin, 2020, Bleizgys, 2020, Musavi et al., 2020, Ali et al., 2018, Andersen et al., 2015, Shen 377 et al., 2017).

378 From a disease perspective, the observed decrease in ace2 expression in the zebrafish SBS 379 model may point to a link between decreased levels of ace2 and inflammation as widely observed 380 in human SBS patients (Schall et al., 2017). Our re-analysis has shown that zebrafish uhrf1 and 381 cdipt mutants, with elevated intestinal inflammation, both exhibit a significant decrease in ace2 382 expression (Marjoram et al., 2015, Thakur et al., 2014). In human inflammatory bowel disease 383 (IBD), ACE2 levels exhibit a similar decrease in inflamed ileum yet increases in inflamed colon 384 and rectum (Suarez-Farinas et al., 2020, Verstockt et al., 2020). In addition, the zebrafish 385 embryos deficient in the key innate immunity regulatory factor myd88 exhibit altered lipid 386 metabolism while expressing ace2 highly, regardless of the type of microbiome (Koch et al., 387 2018). Interestingly, in mice, MyD88 is shown to be essential in protection against SARS-CoV 388 (Hirano and Murakami, 2020, Sheahan et al., 2008). Moreover, our bioinformatics analyses show 389 that preexposure to immune suppressive and lipid modulatory agent $\beta$-glucans may lower ace 2 
390 levels (AbuMweis et al., 2010), all supporting an association between ace2 levels and modulation

391 of inflammatory pathways, which remains to be tested.

392 We observed a sexually dimorphic expression pattern of ace2 in zebrafish, which can provide a

393 model for studying gender-specific ace2 expression in response to different drugs in regard to

394 hypertension as well as COVID-19 treatment (Cuffe et al., 2016, Goyal et al., 2015). Moreover,

395 esr2a knock-out zebrafish, exhibiting a significantly lower female to male offspring ratio (Lu et al.,

396 2017, Wu et al., 2020), also show lower ace2 levels. Previously, a modulatory role of estrogen on

397 ACE2 expression through its receptors, ESR1, or GPER1, has been shown (Feng et al., 2020,

398 Mompeon et al., 2016, Sun et al., 2021). Altogether, our analyses suggest a gender-specific role

399 for ace2 also in zebrafish.

400 In conclusion, tissue and context-dependent expression of ace2 in zebrafish correlate well with

401 the human, non-human primate, and rodent data, as exemplified above. Moreover, via meta-

402 analysis, we provide novel links between ace2 expression modulation and diseases of the

403 intestines and liver for the first time in the zebrafish literature. Our application of logFC based

404 extraction of co-expressed genes of zebrafish ace2 translates into functional networks connected

405 with each other via their common components. These networks were obtained based on

406 heterogeneous datasets, hence reveal a relatively wide range of conditions zebrafish ace2

407 expression could be modulated. A similar meta-analysis approach has been used in compound

408 networks, and herein to zebrafish ace2; hence is easily applicable to species-specific gene

409 networks reflecting differential expression. Furthermore, we provide novel leads for testing

410 zebrafish ace2 levels against different drugs within a given developmental and physiological time-

411 frame as well as different liver and intestinal pathologies.

\section{Competing interests}

413 The authors declare no competing or financial interests. 
ABUMWEIS, S. S., JEW, S. \& AMES, N. P. 2010. beta-glucan from barley and its lipid-lowering capacity: a meta-analysis of randomized, controlled trials. Eur J Clin Nutr, 64, 1472-80.

ALI, R. M., AL-SHORBAGY, M. Y., HELMY, M. W. \& EL-ABHAR, H. S. 2018. Role of Wnt4/beta-catenin, Ang II/TGFbeta, ACE2, NF-kappaB, and IL-18 in attenuating renal ischemia/reperfusion-induced injury in rats treated with Vit $D$ and pioglitazone. Eur J Pharmacol, 831, 68-76.

ALVAREZ-RODRIGUEZ, M., PEREIRO, P., REYES-LOPEZ, F. E., TORT, L., FIGUERAS, A. \& NOVOA, B. 2018. Analysis of the Long-Lived Responses Induced by Immunostimulants and Their Effects on a Viral Infection in Zebrafish (Danio rerio). Front Immunol, 9, 1575.

ANDERS, S., PYL, P. T. \& HUBER, W. 2015. HTSeq--a Python framework to work with high-throughput sequencing data. Bioinformatics, 31, 166-9.

ANDERSEN, L. B., PRZYBYL, L., HAASE, N., VON VERSEN-HOYNCK, F., QADRI, F., JORGENSEN, J. S., SORENSEN, G. L., FRUEKILDE, P., POGLITSCH, M., SZIJARTO, I., GOLLASCH, M., PETERS, J., MULLER, D. N., CHRISTESEN, H. T. \& DECHEND, R. 2015. Vitamin D depletion aggravates hypertension and target-organ damage. J Am Heart Assoc, 4.

ARAMILLO IRIZAR, P., SCHAUBLE, S., ESSER, D., GROTH, M., FRAHM, C., PRIEBE, S., BAUMGART, M., HARTMANN, N., MARTHANDAN, S., MENZEL, U., MULLER, J., SCHMIDT, S., AST, V., CALIEBE, A., KONIG, R., KRAWCZAK, M., RISTOW, M., SCHUSTER, S., CELLERINO, A., DIEKMANN, S., ENGLERT, C., HEMMERICH, P., SUHNEL, J., GUTHKE, R., WITTE, O. W., PLATZER, M., RUPPIN, E. \& KALETA, C. 2018. Transcriptomic alterations during ageing reflect the shift from cancer to degenerative diseases in the elderly. Nat Commun, 9, 327.

BARRETT, T., WILHITE, S. E., LEDOUX, P., EVANGELISTA, C., KIM, I. F., TOMASHEVSKY, M., MARSHALL, K. A., PHILLIPPY, K. H., SHERMAN, P. M., HOLKO, M., YEFANOV, A., LEE, H., ZHANG, N., ROBERTSON, C. L., SEROVA, N., DAVIS, S. \& SOBOLEVA, A. 2013. NCBI GEO: archive for functional genomics data sets--update. Nucleic Acids Res, 41, D991-5.

BENSKIN, L. L. 2020. A Basic Review of the Preliminary Evidence That COVID-19 Risk and Severity Is Increased in Vitamin D Deficiency. Front Public Health, 8, 513.

BLEIZGYS, A. 2020. Vitamin D AND COVID-19: It is time to act. Int J Clin Pract, e13748.

BLERIOT, C. \& GINHOUX, F. 2019. Understanding the Heterogeneity of Resident Liver Macrophages. Front Immunol, 10, 2694.

CAO, X., LU, X. M., TUO, X., LIU, J. Y., ZHANG, Y. C., SONG, L. N., CHENG, Z. Q., YANG, J. K. \& XIN, Z. 2019. Angiotensin-converting enzyme 2 regulates endoplasmic reticulum stress and mitochondrial function to preserve skeletal muscle lipid metabolism. Lipids Health Dis, 18, 207.

CAO, X., YANG, F., SHI, T., YUAN, M., XIN, Z., XIE, R., LI, S., LI, H. \& YANG, J. K. 2016. Angiotensinconverting enzyme 2/angiotensin-(1-7)/Mas axis activates Akt signaling to ameliorate hepatic steatosis. Sci Rep, 6, 21592.

CAO, X., YANG, F. Y., XIN, Z., XIE, R. R. \& YANG, J. K. 2014. The ACE2/Ang-(1-7)/Mas axis can inhibit hepatic insulin resistance. Mol Cell Endocrinol, 393, 30-8.

CHEN, L., MARISHTA, A., ELLISON, C. E. \& VERZI, M. P. 2020a. Identification of Transcription Factors Regulating SARS-CoV-2 Entry Genes in the Intestine. Cell Mol Gastroenterol Hepatol.

CHEN, L., WANG, L., CHENG, Q., TU, Y. X., YANG, Z., LI, R. Z., LUO, Z. H. \& CHEN, Z. X. 2020b. Antimasculinization induced by aromatase inhibitors in adult female zebrafish. BMC Genomics, 21, 22.

CHENG, J. A. Y., LUN 2013. Comparing gene expression similarity metrics for connectivity map. 2013 IEEE International Conference on Bioinformatics and Biomedicine, 165-170. 
CHENG, P. Y., LIN, C. C., WU, C. S., LU, Y. F., LIN, C. Y., CHUNG, C. C., CHU, C. Y., HUANG, C. J., TSAI, C. Y., KORZH, S., WU, J. L. \& HWANG, S. P. 2008. Zebrafish cdx1b regulates expression of downstream factors of Nodal signaling during early endoderm formation. Development, 135, 941-52.

CHENG, Z. \& LIU, Z. 2019. Renin-angiotensin system gene polymorphisms and colorectal cancer risk: a meta-analysis. J Renin Angiotensin Aldosterone Syst, 20, 1470320319881932.

CHEUNG, M. W. \& VIJAYAKUMAR, R. 2016. A Guide to Conducting a Meta-Analysis. Neuropsychol Rev, 26, 121-8.

CHOU, C. F., LOH, C. B., FOO, Y. K., SHEN, S., FIELDING, B. C., TAN, T. H., KHAN, S., WANG, Y., LIM, S. G., HONG, W., TAN, Y. J. \& FU, J. 2006. ACE2 orthologues in non-mammalian vertebrates (Danio, Gallus, Fugu, Tetraodon and Xenopus). Gene, 377, 46-55.

COCCHERI, S. 2020. COVID-19: The crucial role of blood coagulation and fibrinolysis. Intern Emerg Med.

CUFFE, J. S., BURGESS, D. J., O'SULLIVAN, L., SINGH, R. R. \& MORITZ, K. M. 2016. Maternal corticosterone exposure in the mouse programs sex-specific renal adaptations in the renin-angiotensinaldosterone system in 6-month offspring. Physiol Rep, 4.

DOBIN, A., DAVIS, C. A., SCHLESINGER, F., DRENKOW, J., ZALESKI, C., JHA, S., BATUT, P., CHAISSON, M. \& GINGERAS, T. R. 2013. STAR: ultrafast universal RNA-seq aligner. Bioinformatics, 29, 15-21.

DOMAZET-LOSO, T. \& TAUTZ, D. 2010. A phylogenetically based transcriptome age index mirrors ontogenetic divergence patterns. Nature, 468, 815-8.

EVANGELOU, E. \& IOANNIDIS, J. P. 2013. Meta-analysis methods for genome-wide association studies and beyond. Nat Rev Genet, 14, 379-89.

FENG, Q., LI, L. \& WANG, X. 2020. Identifying Pathways and Networks Associated With the SARS-CoV-2 Cell Receptor ACE2 Based on Gene Expression Profiles in Normal and SARS-CoV-2-Infected Human Tissues. Front Mol Biosci, 7, 568954.

FLORES, M. V., HALL, C. J., DAVIDSON, A. J., SINGH, P. P., MAHAGAONKAR, A. A., ZON, L. I., CROSIER, K. E. \& CROSIER, P. S. 2008. Intestinal differentiation in zebrafish requires $\mathrm{Cdx} 1 \mathrm{~b}$, a functional equivalent of mammalian Cdx2. Gastroenterology, 135, 1665-75.

FORN-CUNI, G., VARELA, M., PEREIRO, P., NOVOA, B. \& FIGUERAS, A. 2017. Conserved gene regulation during acute inflammation between zebrafish and mammals. Sci Rep, 7, 41905.

FROEHLICHER, M., LIEDTKE, A., GROH, K., LOPEZ-SCHIER, H., NEUHAUSS, S. C., SEGNER, H. \& EGGEN, R. I. 2009. Estrogen receptor subtype beta2 is involved in neuromast development in zebrafish (Danio rerio) larvae. Dev Biol, 330, 32-43.

GALLAGHER, P. E., FERRARIO, C. M. \& TALLANT, E. A. 2008. MAP kinase/phosphatase pathway mediates the regulation of ACE2 by angiotensin peptides. Am J Physiol Cell Physiol, 295, C1169-74.

GANZ, J., MELANCON, E., WILSON, C., AMORES, A., BATZEL, P., STRADER, M., BRAASCH, I., DIBA, P., KUHLMAN, J. A., POSTLETHWAIT, J. H. \& EISEN, J. S. 2019. Epigenetic factors Dnmt1 and Uhrf1 coordinate intestinal development. Dev Biol, 455, 473-484.

GAUTIER, L., COPE, L., BOLSTAD, B. M. \& IRIZARRY, R. A. 2004. affy--analysis of Affymetrix GeneChip data at the probe level. Bioinformatics, 20, 307-15.

GAVA, E., SAMAD-ZADEH, A., ZIMPELMANN, J., BAHRAMIFARID, N., KITTEN, G. T., SANTOS, R. A., TOUYZ, R. M. \& BURNS, K. D. 2009. Angiotensin-(1-7) activates a tyrosine phosphatase and inhibits glucose-induced signalling in proximal tubular cells. Nephrol Dial Transplant, 24, 1766-73.

GOMES, M. C. \& MOSTOWY, S. 2020. The Case for Modeling Human Infection in Zebrafish. Trends Microbiol, 28, 10-18.

GOYAL, R., VAN-WICKLE, J., GOYAL, D. \& LONGO, L. D. 2015. Antenatal maternal low protein diet: ACE-2 in the mouse lung and sexually dimorphic programming of hypertension. BMC Physiol, 15, 2.

GUPTE, M., BOUSTANY-KARI, C. M., BHARADWAJ, K., POLICE, S., THATCHER, S., GONG, M. C., ENGLISH, V. L. \& CASSIS, L. A. 2008. ACE2 is expressed in mouse adipocytes and regulated by a high-fat diet. Am J Physiol Regul Integr Comp Physiol, 295, R781-8. 
GUR-DEDEOGLU, B., KONU, O., KIR, S., OZTURK, A. R., BOZKURT, B., ERGUL, G. \& YULUG, I. G. 2008. A resampling-based meta-analysis for detection of differential gene expression in breast cancer. BMC Cancer, 8, 396.

GWATHMEY, T. M., PENDERGRASS, K. D., REID, S. D., ROSE, J. C., DIZ, D. I. \& CHAPPELL, M. C. 2010. Angiotensin-(1-7)-angiotensin-converting enzyme 2 attenuates reactive oxygen species formation to angiotensin II within the cell nucleus. Hypertension, 55, 166-71.

HAMMING, I., COOPER, M. E., HAAGMANS, B. L., HOOPER, N. M., KORSTANJE, R., OSTERHAUS, A. D., TIMENS, W., TURNER, A. J., NAVIS, G. \& VAN GOOR, H. 2007. The emerging role of ACE2 in physiology and disease. J Pathol, 212, 1-11.

HEIDEN, T. C., STRUBLE, C. A., RISE, M. L., HESSNER, M. J., HUTZ, R. J. \& CARVAN, M. J., 3RD 2008. Molecular targets of 2,3,7,8-tetrachlorodibenzo-p-dioxin (TCDD) within the zebrafish ovary: insights into TCDD-induced endocrine disruption and reproductive toxicity. Reprod Toxicol, 25, 47-57.

HIRANO, T. \& MURAKAMI, M. 2020. COVID-19: A New Virus, but a Familiar Receptor and Cytokine Release Syndrome. Immunity, 52, 731-733.

HOLDEN, L. A. \& BROWN, K. H. 2018. Baseline mRNA expression differs widely between common laboratory strains of zebrafish. Sci Rep, 8, 4780.

HU, B., CHEN, H., LIU, X., ZHANG, C., COLE, G. J., LEE, J. A. \& CHEN, X. 2013. Transgenic overexpression of $\mathrm{cdx} 1 \mathrm{~b}$ induces metaplastic changes of gene expression in zebrafish esophageal squamous epithelium. Zebrafish, 10, 218-27.

JACOB, V., CHERNYAVSKAYA, Y., CHEN, X., TAN, P. S., KENT, B., HOSHIDA, Y. \& SADLER, K. C. 2015. DNA hypomethylation induces a DNA replication-associated cell cycle arrest to block hepatic outgrowth in uhrf1 mutant zebrafish embryos. Development, 142, 510-21.

JIA, H. P., LOOK, D. C., SHI, L., HICKEY, M., PEWE, L., NETLAND, J., FARZAN, M., WOHLFORD-LENANE, C., PERLMAN, S. \& MCCRAY, P. B., JR. 2005. ACE2 receptor expression and severe acute respiratory syndrome coronavirus infection depend on differentiation of human airway epithelia. J Virol, 79, 14614-21.

JIA, J., QIN, J., YUAN, X., LIAO, Z., HUANG, J., WANG, B., SUN, C. \& LI, W. 2019. Microarray and metabolome analysis of hepatic response to fasting and subsequent refeeding in zebrafish (Danio rerio). BMC Genomics, 20, 919.

JOHNSON, E., VU, L. \& MATARESE, L. E. 2018. Bacteria, Bones, and Stones: Managing Complications of Short Bowel Syndrome. Nutr Clin Pract, 33, 454-466.

KIM, S. M., KIM, Y. G., JEONG, K. H., LEE, S. H., LEE, T. W., IHM, C. G. \& MOON, J. Y. 2012. Angiotensin IIinduced mitochondrial Nox4 is a major endogenous source of oxidative stress in kidney tubular cells. PLoS One, 7, e39739.

KIMMEL, C. B., BALLARD, W. W., KIMMEL, S. R., ULLMANN, B. \& SCHILLING, T. F. 1995. Stages of embryonic development of the zebrafish. Dev Dyn, 203, 253-310.

KOCH, B. E. V., YANG, S., LAMERS, G., STOUGAARD, J. \& SPAINK, H. P. 2018. Intestinal microbiome adjusts the innate immune setpoint during colonization through negative regulation of MyD88. Nat Commun, 9, 4099.

KOLDE, R., LAUR, S., ADLER, P. \& VILO, J. 2012. Robust rank aggregation for gene list integration and meta-analysis. Bioinformatics, 28, 573-80.

KRAMER, S., BUSCH, W. \& SCHUTTLER, A. 2020. A Self-Organizing Map of the Fathead Minnow Liver Transcriptome to Identify Consistent Toxicogenomic Patterns across Chemical Fingerprints. Environ Toxicol Chem, 39, 526-537.

KRYUCHKOVA-MOSTACCI, N. \& ROBINSON-RECHAVI, M. 2017. A benchmark of gene expression tissuespecificity metrics. Brief Bioinform, 18, 205-214. 
LEE, I. T., NAKAYAMA, T., WU, C. T., GOLTSEV, Y., JIANG, S., GALL, P. A., LIAO, C. K., SHIH, L. C., SCHURCH, C. M., MCILWAIN, D. R., CHU, P., BORCHARD, N. A., ZARABANDA, D., DHOLAKIA, S. S., YANG, A., KIM, D., CHEN, H., KANIE, T., LIN, C. D., TSAI, M. H., PHILLIPS, K. M., KIM, R., OVERDEVEST, J. B., TYLER, M. A., YAN, C. H., LIN, C. F., LIN, Y. T., BAU, D. T., TSAY, G. J., PATEL, Z. M., TSOU, Y. A., TZANKOV, A., MATTER, M. S., TAI, C. J., YEH, T. H., HWANG, P. H., NOLAN, G. P., NAYAK, J. V. \& JACKSON, P. K. 2020a. ACE2 localizes to the respiratory cilia and is not increased by ACE inhibitors or ARBs. Nat Commun, 11, 5453.

LEE, I. T., NAKAYAMA, T., WU, C. T., GOLTSEV, Y., JIANG, S., GALL, P. A., LIAO, C. K., SHIH, L. C., SCHURCH, C. M., MCILWAIN, D. R., CHU, P., BORCHARD, N. A., ZARABANDA, D., DHOLAKIA, S. S., YANG, A., KIM, D., KANIE, T., LIN, C. D., TSAI, M. H., PHILLIPS, K. M., KIM, R., OVERDEVEST, J. B., TYLER, M. A., YAN, C. H., LIN, C. F., LIN, Y. T., BAU, D. T., TSAY, G. J., PATEL, Z. M., TSOU, Y. A., TAI, C. J., YEH, T. H., HWANG, P. H., NOLAN, G. P., NAYAK, J. V. \& JACKSON, P. K. 2020b. Robust ACE2 protein expression localizes to the motile cilia of the respiratory tract epithelia and is not increased by ACE inhibitors or angiotensin receptor blockers. medRxiv.

LIU, W., QIAO, Q., CHEN, Y., WU, K. \& ZHANG, X. 2014. Microcystin-LR exposure to adult zebrafish (Danio rerio) leads to growth inhibition and immune dysfunction in F1 offspring, a parental transmission effect of toxicity. Aquat Toxicol, 155, 360-7.

LOGAN, S. L., THOMAS, J., YAN, J., BAKER, R. P., SHIELDS, D. S., XAVIER, J. B., HAMMER, B. K. \& PARTHASARATHY, R. 2018. The Vibrio cholerae type VI secretion system can modulate host intestinal mechanics to displace gut bacterial symbionts. Proc Natl Acad Sci U S A, 115, E3779E3787.

LOVE, M. I., HUBER, W. \& ANDERS, S. 2014. Moderated estimation of fold change and dispersion for RNA-seq data with DESeq2. Genome Biol, 15, 550.

LU, H., CUI, Y., JIANG, L. \& GE, W. 2017. Functional Analysis of Nuclear Estrogen Receptors in Zebrafish Reproduction by Genome Editing Approach. Endocrinology, 158, 2292-2308.

MACINNES, A. W., AMSTERDAM, A., WHITTAKER, C. A., HOPKINS, N. \& LEES, J. A. 2008. Loss of p53 synthesis in zebrafish tumors with ribosomal protein gene mutations. Proc Natl Acad Sci U SA, 105, 10408-13.

MARJORAM, L., ALVERS, A., DEERHAKE, M. E., BAGWELL, J., MANKIEWICZ, J., COCCHIARO, J. L., BEERMAN, R. W., WILLER, J., SUMIGRAY, K. D., KATSANIS, N., TOBIN, D. M., RAWLS, J. F., GOLL, M. G. \& BAGNAT, M. 2015. Epigenetic control of intestinal barrier function and inflammation in zebrafish. Proc Natl Acad Sci U S A, 112, 2770-5.

MCCARTHY, D. J., CHEN, Y. \& SMYTH, G. K. 2012. Differential expression analysis of multifactor RNA-Seq experiments with respect to biological variation. Nucleic Acids Res, 40, 4288-97.

MICKIEWICZ, K. M., KAWAI, Y., DRAGE, L., GOMES, M. C., DAVISON, F., PICKARD, R., HALL, J., MOSTOWY, S., ALDRIDGE, P. D. \& ERRINGTON, J. 2019. Possible role of L-form switching in recurrent urinary tract infection. Nat Commun, 10, 4379.

MOMPEON, A., LAZARO-FRANCO, M., BUENO-BETI, C., PEREZ-CREMADES, D., VIDAL-GOMEZ, X., MONSALVE, E., GIRONACCI, M. M., HERMENEGILDO, C. \& NOVELLA, S. 2016. Estradiol, acting through ERalpha, induces endothelial non-classic renin-angiotensin system increasing angiotensin 1-7 production. Mol Cell Endocrinol, 422, 1-8.

MUSAVI, H., ABAZARI, O., BARARTABAR, Z., KALAKI-JOUYBARI, F., HEMMATI-DINARVAND, M., ESMAEILI, P. \& MAHJOUB, S. 2020. The benefits of Vitamin D in the COVID-19 pandemic: biochemical and immunological mechanisms. Arch Physiol Biochem, 1-9.

MUTANEN, A., BARRETT, M., FENG, Y., LOHI, J., RABAH, R., TEITELBAUM, D. H. \& PAKARINEN, M. P. 2019. Short bowel mucosal morphology, proliferation and inflammation at first and repeat STEP procedures. J Pediatr Surg, 54, 511-516. 
601

602

603

604

605

606

607

608

609

610

611

612

613

614

615

616

617

NEHME, A., ZOUEIN, F. A., ZAYERI, Z. D. \& ZIBARA, K. 2019. An Update on the Tissue Renin Angiotensin System and Its Role in Physiology and Pathology. J Cardiovasc Dev Dis, 6.

OKUDA, Y., OGURA, E., KONDOH, H. \& KAMACHI, Y. 2010. B1 SOX coordinate cell specification with patterning and morphogenesis in the early zebrafish embryo. PLoS Genet, 6, e1000936.

PAPATHEODOROU, I., MORENO, P., MANNING, J., FUENTES, A. M., GEORGE, N., FEXOVA, S., FONSECA, N. A., FUlLGRABE, A., GREEN, M., HUANG, N., HUERTA, L., IQBAL, H., JIANU, M., MOHAMMED, S., ZHAO, L., JARNUCZAK, A. F., JUPP, S., MARIONI, J., MEYER, K., PETRYSZAK, R., PRADA MEDINA, C. A., TALAVERA-LOPEZ, C., TEICHMANN, S., VIZCAINO, J. A. \& BRAZMA, A. 2020. Expression Atlas update: from tissues to single cells. Nucleic Acids Res, 48, D77-D83.

PINTER, M. \& JAIN, R. K. 2017. Targeting the renin-angiotensin system to improve cancer treatment: Implications for immunotherapy. Sci Transl Med, 9.

POSTLETHWAIT, J. H., MASSAQUOI, M. S., FARNSWORTH, D. R., YAN, Y. L., GUILLEMIN, K. \& MILLER, A. C. 2021. The SARS-CoV-2 receptor and other key components of the Renin-AngiotensinAldosterone System related to COVID-19 are expressed in enterocytes in larval zebrafish. Biol Open, 10.

RASHA, F., RAMALINGAM, L., GOLLAHON, L., RAHMAN, R. L., RAHMAN, S. M., MENIKDIWELA, K. \& MOUSTAID-MOUSSA, N. 2019. Mechanisms linking the renin-angiotensin system, obesity, and breast cancer. Endocr Relat Cancer, 26, R653-R672.

RITCHIE, M. E., PHIPSON, B., WU, D., HU, Y., LAW, C. W., SHI, W. \& SMYTH, G. K. 2015. limma powers differential expression analyses for RNA-sequencing and microarray studies. Nucleic Acids Res, 43, e47.

ROBINSON, M. W., HARMON, C. \& O'FARRELLY, C. 2016. Liver immunology and its role in inflammation and homeostasis. Cell Mol Immunol, 13, 267-76.

ROBISON, B. D., DREW, R. E., MURDOCH, G. K., POWELL, M., RODNICK, K. J., SETTLES, M., STONE, D., CHURCHILL, E., HILL, R. A., PAPASANI, M. R., LEWIS, S. S. \& HARDY, R. W. 2008. Sexual dimorphism in hepatic gene expression and the response to dietary carbohydrate manipulation in the zebrafish (Danio rerio). Comp Biochem Physiol Part D Genomics Proteomics, 3, 141-54.

ROGERS, E. D., HENRY, T. B., TWINER, M. J., GOUFFON, J. S., MCPHERSON, J. T., BOYER, G. L., SAYLER, G. S. \& WILHELM, S. W. 2011. Global gene expression profiling in larval zebrafish exposed to microcystin-LR and microcystis reveals endocrine disrupting effects of Cyanobacteria. Environ Sci Technol, 45, 1962-9.

SAN, B., ABEN, M., ELURBE, D. M., VOELTZKE, K., DEN BROEDER, M. J., ROUGEOT, J., LEGLER, J. \& KAMMINGA, L. M. 2018. Genetic and epigenetic regulation of zebrafish intestinal development. Epigenomes, 2, 19.

SCHALL, K. A., THORNTON, M. E., ISANI, M., HOLOYDA, K. A., HOU, X., LIEN, C. L., GRUBBS, B. H. \& GRIKSCHEIT, T. C. 2017. Short bowel syndrome results in increased gene expression associated with proliferation, inflammation, bile acid synthesis and immune system activation: RNA sequencing a zebrafish SBS model. BMC Genomics, 18, 23.

SHANNON, P., MARKIEL, A., OZIER, O., BALIGA, N. S., WANG, J. T., RAMAGE, D., AMIN, N., SCHWIKOWSKI, B. \& IDEKER, T. 2003. Cytoscape: a software environment for integrated models of biomolecular interaction networks. Genome Res, 13, 2498-504.

SHEAHAN, T., MORRISON, T. E., FUNKHOUSER, W., UEMATSU, S., AKIRA, S., BARIC, R. S. \& HEISE, M. T. 2008. MyD88 is required for protection from lethal infection with a mouse-adapted SARS-CoV. PLoS Pathog, 4, e1000240.

SHEHWANA, H. \& KONU, O. 2019. Comparative Transcriptomics Between Zebrafish and Mammals: A Roadmap for Discovery of Conserved and Unique Signaling Pathways in Physiology and Disease. Front Cell Dev Biol, 7, 5. 
648

SHEN, L., MA, C., SHUAI, B. \& YANG, Y. 2017. Effects of 1,25-dihydroxyvitamin D3 on the local bone renin-angiotensin system in a murine model of glucocorticoid-induced osteoporosis. Exp Ther Med, 13, 3297-3304.

SHI, T. T., YANG, F. Y., LIU, C., CAO, X., LU, J., ZHANG, X. L., YUAN, M. X., CHEN, C. \& YANG, J. K. 2018. Angiotensin-converting enzyme 2 regulates mitochondrial function in pancreatic beta-cells. Biochem Biophys Res Commun, 495, 860-866.

SHOEMAKER, R., TANNOCK, L. R., SU, W., GONG, M., GURLEY, S. B., THATCHER, S. E., YIANNIKOURIS, F., ENSOR, C. M. \& CASSIS, L. A. 2019. Adipocyte deficiency of ACE2 increases systolic blood pressures of obese female C57BL/6 mice. Biol Sex Differ, 10, 45.

SILBERG, D. G., SWAIN, G. P., SUH, E. R. \& TRABER, P. G. 2000. Cdx1 and cdx2 expression during intestinal development. Gastroenterology, 119, 961-71.

SMALL, C. M., CARNEY, G. E., MO, Q., VANNUCCI, M. \& JONES, A. G. 2009. A microarray analysis of sexand gonad-biased gene expression in the zebrafish: evidence for masculinization of the transcriptome. BMC Genomics, 10, 579.

SONG, L. N., LIU, J. Y., SHI, T. T., ZHANG, Y. C., XIN, Z., CAO, X. \& YANG, J. K. 2020. Angiotensin-(1-7), the product of ACE2 ameliorates NAFLD by acting through its receptor Mas to regulate hepatic mitochondrial function and glycolipid metabolism. FASEB J.

SONG, R., PRESTON, G. \& YOSYPIV, I. V. 2012. Ontogeny of angiotensin-converting enzyme 2. Pediatr Res, 71, 13-9.

SONI, K., CHOUDHARY, A., PATOWARY, A., SINGH, A. R., BHATIA, S., SIVASUBBU, S., CHANDRASEKARAN, S. \& PILLAI, B. 2013. miR-34 is maternally inherited in Drosophila melanogaster and Danio rerio. Nucleic Acids Res, 41, 4470-80.

STUCKENHOLZ, C., LU, L., THAKUR, P., KAMINSKI, N. \& BAHARY, N. 2009. FACS-assisted microarray profiling implicates novel genes and pathways in zebrafish gastrointestinal tract development. Gastroenterology, 137, 1321-32.

SUAREZ-FARINAS, M., TOKUYAMA, M., WEI, G., HUANG, R., LIVANOS, A., JHA, D., LEVESCOT, A., IRIZAR, H., KOSOY, R., CORDING, S., WANG, W., LOSIC, B., UNGARO, R., DI'NARZO, A., MARTINEZDELGADO, G., SUPRUN, M., CORLEY, M. J., STOJMIROVIC, A., HOUTEN, S. M., PETERS, L., CURRAN, M., BRODMERKEL, C., PERRIGOUE, J., FRIEDMAN, J. R., HAO, K., SCHADT, E. E., ZHU, J., KO, H. M., CHO, J., DUBINSKY, M. C., SANDS, B. E., NDHLOVU, L., CERF-BENSUSAN, N., KASARSKIS, A., COLOMBEL, J. F., HARPAZ, N., ARGMANN, C. \& MEHANDRU, S. 2020. Intestinal inflammation modulates the expression of ACE2 and TMPRSS2 and potentially overlaps with the pathogenesis of SARS-CoV-2 related disease. Gastroenterology.

SUN, X., WANG, H., HODGE, H., WRIGHT, K. N., AHMAD, S., FERRARIO, C. M. \& GROBAN, L. 2021. Amplifying effect of chronic lisinopril therapy on diastolic function and the angiotensin-(1-7) Axis by the G1 agonist in ovariectomized spontaneously hypertensive rats. Trans/ Res, 235, 62-76.

SZKLARCZYK, D., FRANCESCHINI, A., WYDER, S., FORSLUND, K., HELLER, D., HUERTA-CEPAS, J., SIMONOVIC, M., ROTH, A., SANTOS, A., TSAFOU, K. P., KUHN, M., BORK, P., JENSEN, L. J. \& VON MERING, C. 2015. STRING v10: protein-protein interaction networks, integrated over the tree of life. Nucleic Acids Res, 43, D447-52.

SZKLARCZYK, D., GABLE, A. L., LYON, D., JUNGE, A., WYDER, S., HUERTA-CEPAS, J., SIMONOVIC, M., DONCHEVA, N. T., MORRIS, J. H., BORK, P., JENSEN, L. J. \& MERING, C. V. 2019. STRING V11: protein-protein association networks with increased coverage, supporting functional discovery in genome-wide experimental datasets. Nucleic Acids Res, 47, D607-D613.

TER VEER, E., VAN OIJEN, M. G. H. \& VAN LAARHOVEN, H. W. M. 2019. The Use of (Network) MetaAnalysis in Clinical Oncology. Front Oncol, 9, 822. 
694

695

696

697

698

699

700

701

702

703

704

705

706

707

708

709

710

711

712

713

714

715

716

717

718

719

720

721

722

723

724

725

726

727

728

729

730

731

732

733

734

735

736

737

738

739

740

THAKUR, P. C., DAVISON, J. M., STUCKENHOLZ, C., LU, L. \& BAHARY, N. 2014. Dysregulated phosphatidylinositol signaling promotes endoplasmic-reticulum-stress-mediated intestinal mucosal injury and inflammation in zebrafish. Dis Model Mech, 7, 93-106.

TSENG, G. C., GHOSH, D. \& FEINGOLD, E. 2012. Comprehensive literature review and statistical considerations for microarray meta-analysis. Nucleic Acids Res, 40, 3785-99.

VARGAS, M., SERVILLO, G. \& EINAV, S. 2020. Lopinavir/ritonavir for the treatment of SARS, MERS and COVID-19: a systematic review. Eur Rev Med Pharmacol Sci, 24, 8592-8605.

VERSTOCKT, B., VERSTOCKT, S., ABDU RAHIMAN, S., KE, B. J., ARNAUTS, K., CLEYNEN, I., SABINO, J., FERRANTE, M., MATTEOLI, G. \& VERMEIRE, S. 2020. Intestinal receptor of SARS-CoV-2 in inflamed IBD tissue seems downregulated by HNF4A in ileum and upregulated by interferon regulating factors in colon. $J$ Crohns Colitis.

WANG, Y., WANG, Y., LUO, W., HUANG, L., XIAO, J., LI, F., QIN, S., SONG, X., WU, Y., ZENG, Q., JIN, F. \& WANG, Y. 2020. A comprehensive investigation of the mRNA and protein level of ACE2, the putative receptor of SARS-CoV-2, in human tissues and blood cells. Int J Med Sci, 17, 1522-1531.

WHITE, R. J., COLLINS, J. E., SEALY, I. M., WALI, N., DOOLEY, C. M., DIGBY, Z., STEMPLE, D. L., MURPHY, D. N., BILLIS, K., HOURLIER, T., FULLGRABE, A., DAVIS, M. P., ENRIGHT, A. J. \& BUSCH-NENTWICH, E. M. 2017. A high-resolution mRNA expression time course of embryonic development in zebrafish. Elife, 6.

WILLIS, A. R., MOORE, C., MAZON-MOYA, M., KROKOWSKI, S., LAMBERT, C., TILL, R., MOSTOWY, S. \& SOCKETT, R. E. 2016. Injections of Predatory Bacteria Work Alongside Host Immune Cells to Treat Shigella Infection in Zebrafish Larvae. Curr Biol, 26, 3343-3351.

WOOLBRIGHT, B. L., WILLIAMS, C. D., NI, H., KUMER, S. C., SCHMITT, T., KANE, B. \& JAESCHKE, H. 2017. Microcystin-LR induced liver injury in mice and in primary human hepatocytes is caused by oncotic necrosis. Toxicon, 125, 99-109.

WU, K., SONG, W., ZHANG, Z. \& GE, W. 2020. Disruption of dmrt1 rescues the all-male phenotype of the cyp19a1a mutant in zebrafish - a novel insight into the roles of aromatase/estrogens in gonadal differentiation and early folliculogenesis. Development, 147.

YANG, M., MA, X., XUAN, X., DENG, H., CHEN, Q. \& YUAN, L. 2020. Liraglutide Attenuates Non-Alcoholic Fatty Liver Disease in Mice by Regulating the Local Renin-Angiotensin System. Front Pharmacol, $11,432$.

YAO, T. T., QIAN, J. D., ZHU, W. Y., WANG, Y. \& WANG, G. Q. 2020. A systematic review of lopinavir therapy for SARS coronavirus and MERS coronavirus-A possible reference for coronavirus disease-19 treatment option. J Med Virol, 92, 556-563.

YILDIZ, G., ARSLAN-ERGUL, A., BAGISLAR, S., KONU, O., YUZUGULLU, H., GURSOY-YUZUGULLU, O., OZTURK, N., OZEN, C., OZDAG, H., ERDAL, E., KARADEMIR, S., SAGOL, O., MIZRAK, D., BOZKAYA, H., ILK, H. G., ILK, O., BILEN, B., CETIN-ATALAY, R., AKAR, N. \& OZTURK, M. 2013. Genome-wide transcriptional reorganization associated with senescence-to-immortality switch during human hepatocellular carcinogenesis. PLoS One, 8, e64016.

YOON, S., NGUYEN, H. C. T., JO, W., KIM, J., CHI, S. M., PARK, J., KIM, S. Y. \& NAM, D. 2019. Biclustering analysis of transcriptome big data identifies condition-specific microRNA targets. Nucleic Acids Res, 47, e53.

YU, G., WANG, L. G., HAN, Y. \& HE, Q. Y. 2012. clusterProfiler: an R package for comparing biological themes among gene clusters. OMICS, 16, 284-7.

YUAN, J., FAN, D., XUE, Z., QU, J. \& SU, J. 2020. Co-Expression of Mitochondrial Genes and ACE2 in Cornea Involved in COVID-19. Invest Ophthalmol Vis Sci, 61, 13.

ZEITUNI, E. M., WILSON, M. H., ZHENG, X., IGLESIAS, P. A., SEPANSKI, M. A., SIDDIQI, M. A., ANDERSON, J. L., ZHENG, Y. \& FARBER, S. A. 2016. Endoplasmic Reticulum Lipid Flux Influences Enterocyte 
Nuclear Morphology and Lipid-dependent Transcriptional Responses. J Biol Chem, 291, 2380423816.

ZHANG, W., XU, Y. Z., LIU, B., WU, R., YANG, Y. Y., XIAO, X. Q. \& ZHANG, X. 2014. Pioglitazone upregulates angiotensin converting enzyme 2 expression in insulin-sensitive tissues in rats with high-fat diet-induced nonalcoholic steatohepatitis. ScientificWorldJournal, 2014, 603409.

ZHOU, X., WANG, M., KATSYV, I., IRIE, H. \& ZHANG, B. 2018. EMUDRA: Ensemble of Multiple Drug Repositioning Approaches to improve prediction accuracy. Bioinformatics, 34, 3151-3159.

ZIEGLER, C. G. K., ALLON, S. J., NYQUIST, S. K., MBANO, I. M., MIAO, V. N., TZOUANAS, C. N., CAO, Y., YOUSIF, A. S., BALS, J., HAUSER, B. M., FELDMAN, J., MUUS, C., WADSWORTH, M. H., 2ND, KAZER, S. W., HUGHES, T. K., DORAN, B., GATTER, G. J., VUKOVIC, M., TALIAFERRO, F., MEAD, B. E., GUO, Z., WANG, J. P., GRAS, D., PLAISANT, M., ANSARI, M., ANGELIDIS, I., ADLER, H., SUCRE, J. M. S., TAYLOR, C. J., LIN, B., WAGHRAY, A., MITSIALIS, V., DWYER, D. F., BUCHHEIT, K. M., BOYCE, J. A., BARRETT, N. A., LAIDLAW, T. M., CARROLL, S. L., COLONNA, L., TKACHEV, V., PETERSON, C. W., YU, A., ZHENG, H. B., GIDEON, H. P., WINCHELL, C. G., LIN, P. L., BINGLE, C. D., SNAPPER, S. B., KROPSKI, J. A., THEIS, F. J., SCHILLER, H. B., ZARAGOSI, L. E., BARBRY, P., LESLIE, A., KIEM, H. P., FLYNN, J. L., FORTUNE, S. M., BERGER, B., FINBERG, R. W., KEAN, L. S., GARBER, M., SCHMIDT, A. G., LINGWOOD, D., SHALEK, A. K., ORDOVAS-MONTANES, J., LUNGNETWORK@HUMANCELLATLAS.ORG, H. C. A. L. B. N. E. A. \& NETWORK, H. C. A. L. B. 2020. SARSCoV-2 Receptor ACE2 Is an Interferon-Stimulated Gene in Human Airway Epithelial Cells and Is Detected in Specific Cell Subsets across Tissues. Cell, 181, 1016-1035 e19.

\section{Figure Legends}

Figure 1. Carboxypeptidase (A) and Intraflagellar (B) networks colored according to $r_{a c e 2-l o g F C}$ values across GPL1319 datasets $\left(n_{\text {dataset }}=107 ; n_{\text {comparison }}=344\right)$.

Figure 2. ace2 expression patterns during developmental stages from GSE24616, where min, d, and h refer to minutes, days, and hours, respectively (A) and GSE38575, where EtOH, VD, and dpf refer to ethanol, vitamin $D$, and days post-fertilization, respectively (B); and correlation between significantly modulated STRING local network enrichment scores obtained using $r_{\text {ace2 }}$ values using developmental datasets (C).

Figure 3. Top 15 positively and negatively enriched networks using $r_{a c e 2}$ values obtained STRING local network analysis of GSE24616 and GSE38575 focusing on zebrafish early development.

Figure 4. Selected common positively enriched networks using $r_{a c e 2}$ values during zebrafish development. Each node represents an enriched network, and edge weights represent the number of shared genes. They are colored according to the enrichment score. 
774 Figure 5. Selected common negatively enriched networks with $r_{a c e 2}$ values during zebrafish 775 development. Each node represents an enriched network, and edge weights represent the 776 number of shared genes. They are colored according to the enrichment score.

777 Figure 6. Sexual dimorphic expression pattern in adulthood based on GSE24616 (Simple effect 778 analysis following Two-Way ANOVA results were represented. * , p-value < 0.05) (A). Tissue779 specific expression of ace2 $(\log 2(\mathrm{RPKM}+1))$ in the intestines $(731.1)$ and liver $(432.8)$ and the 780 relatively low expression in the gills (1.57), brain (1.08), kidney (0.83), heart (0.62), and muscle 781 (0.49) in the six-month-old zebrafish cohort (B).

782 Figure 7. ace2 expression from GSE12189 where GFP+ and GFP- refer to cells in and out of 783 digestive tract, respectively (A, Limma results were represented. * adj. p-value <0.05; ${ }^{* *}$, adj. p784 value $<0.01{ }^{* * *}$, adj. $p$-value $<0.001 ;^{* * * *}$, adj. $p$-value $\left.<0.0001\right)$. Correlation between the 785 significantly modulated STRING local networks obtained using $r_{\text {ace2 }}$ values in GSE12189 and 786 GSE35889 intestine-specific datasets (B). Bar plots of significant STRING local network 787 enrichment scores for GSE12189 and GSE35889 (C).

788 Figure 8. ace2 expression during immune response in myd88 knock-out (Myd88KO) model with 789 bacterial colonization (Conventionalization (CONVD), Exiguobacterium (Exi) and 790 Chryseobacterium (Chrys)) (Tukey HSD corrected One-way ANOVA results were represented. *, 791 adj. p-value <0.05; ${ }^{* * * *}$, adj. p-value < 0.0001) (A); in viral infection (SVCV: Spring Viraemia Carp 792 Virus) after pre-treatment with the viral medium (MEM), $\beta$-glucans, lipopolysaccharide (LPS), or 793 Polyinosinic:polycytidylic acid (Polyl:C) (Simple effect analysis following Two-Way ANOVA results 794 were represented. *; p-value < 0.05) (B).

795 Figure 9. Bar plots of significant STRING local network enrichment scores for GSE74244 and 796 GSE100583 liver datasets (A); ace2 expression in zebrafish livers during fasting and refed 797 conditions (B); in microcystin-LR (MCLR) exposure $\left({ }^{*}\right.$, p-value < 0.05; ${ }^{* *}$, p-value $\left.<0.01\right)(C)$. 
A

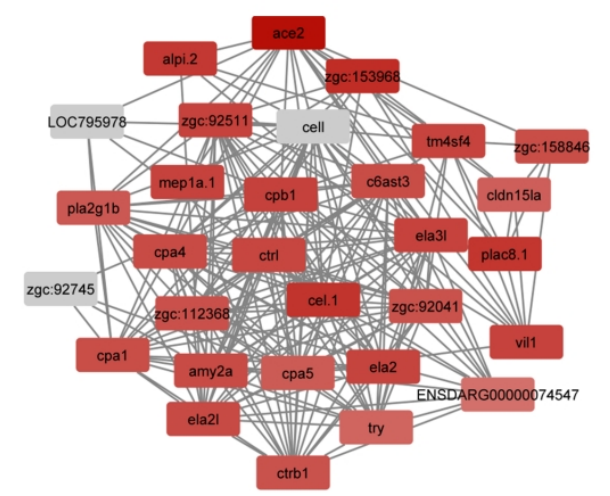

B

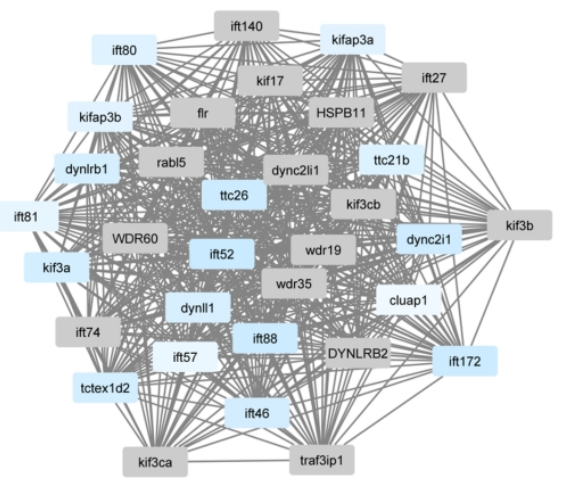

Figure 1. Carboxypeptidase (A) and Intraflagellar (B) networks colored according to race2-logFC values across GPL1319 datasets (ndataset $=107$; ncomparison $=344$ ).

$205 \times 100 \mathrm{~mm}(300 \times 300 \mathrm{DPI})$ 

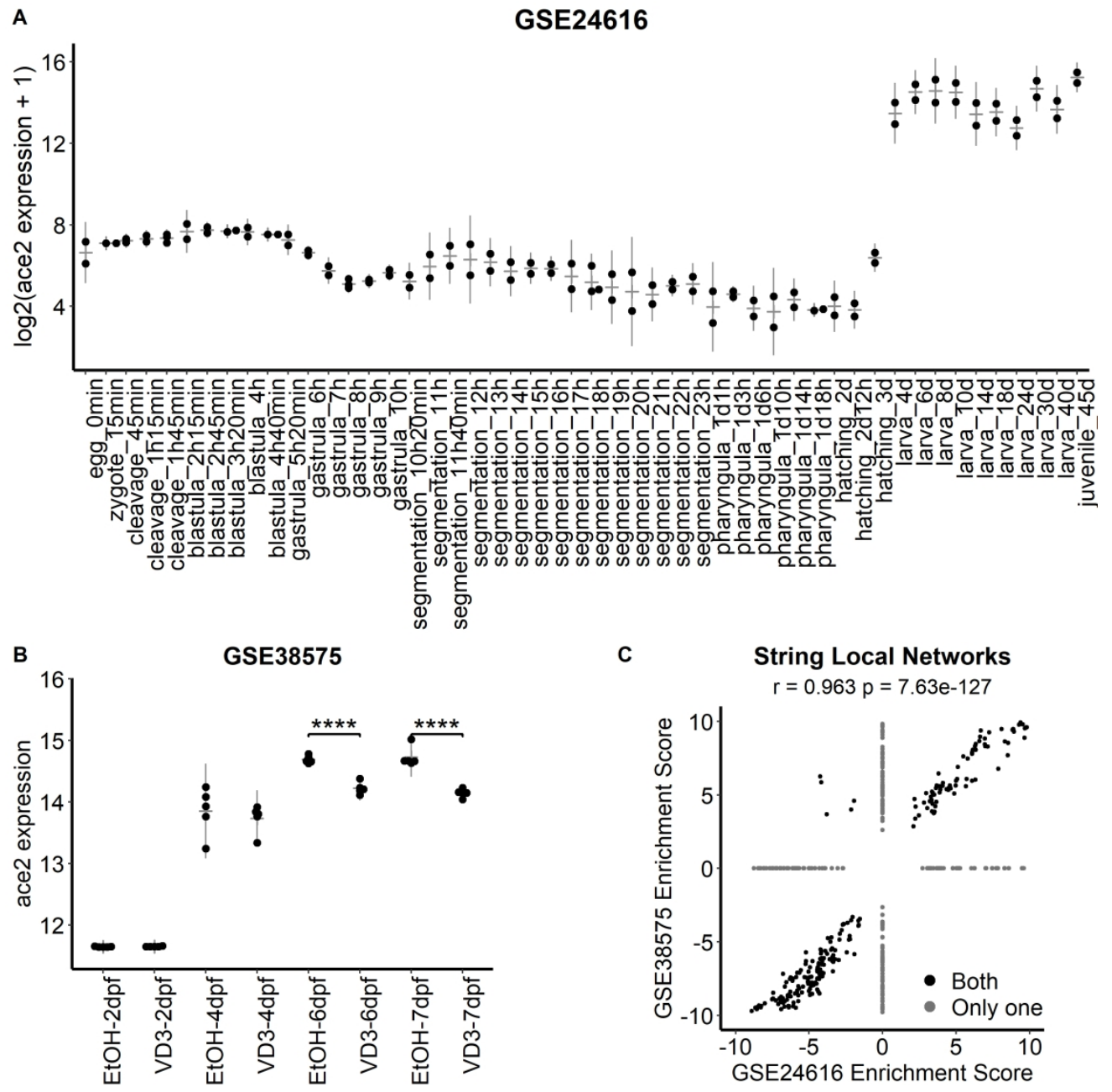

Figure 2. ace2 expression patterns during developmental stages from GSE24616, where min, d, and h refer to minutes, days, and hours, respectively (A) and GSE38575, where EtOH, VD, and dpf refer to ethanol, vitamin $D$, and days post-fertilization, respectively (B); and correlation between significantly modulated STRING local network enrichment scores obtained using race2 values using developmental datasets (C).

$$
254 \times 254 \mathrm{~mm}(300 \times 300 \text { DPI) }
$$




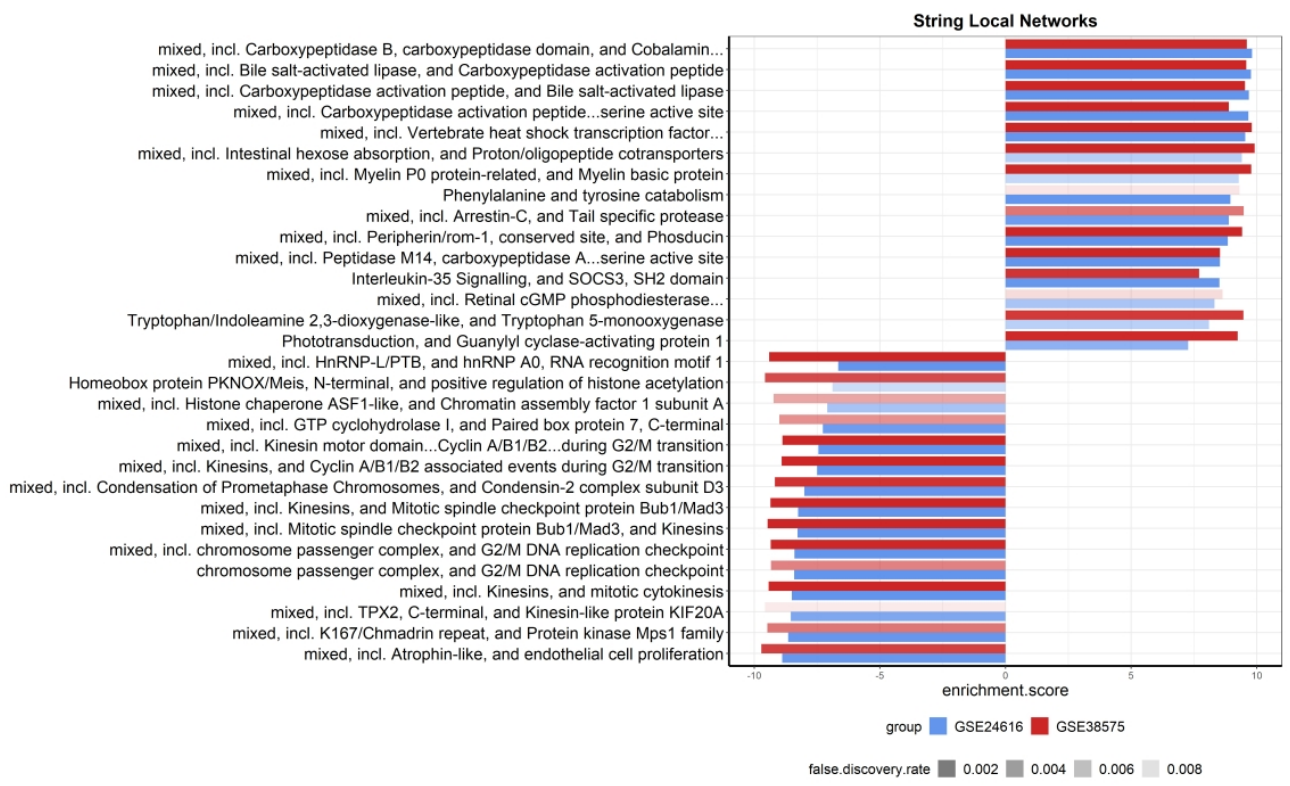

Figure 3. Top 15 positively and negatively enriched networks using race2 values obtained STRING local network analysis of GSE24616 and GSE38575 focusing on zebrafish early development

$423 \times 254 \mathrm{~mm}(300 \times 300 \mathrm{DPI})$ 

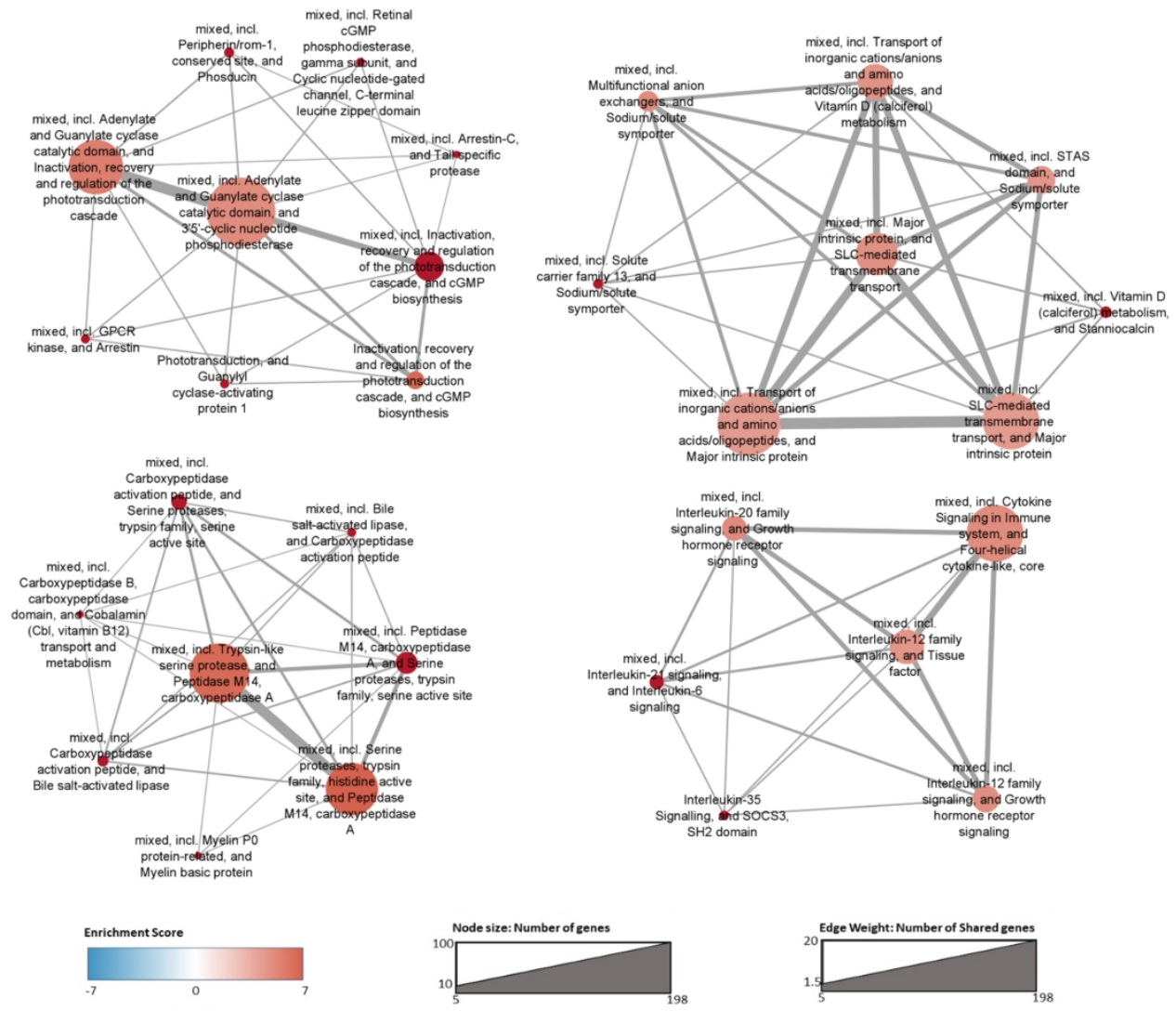

Figure 4. Selected common positively enriched networks using race2 values during zebrafish development. Each node represents an enriched network, and edge weights represent the number of shared genes. They are colored according to the enrichment score.

$176 \times 161 \mathrm{~mm}(300 \times 300 \mathrm{DPI})$ 

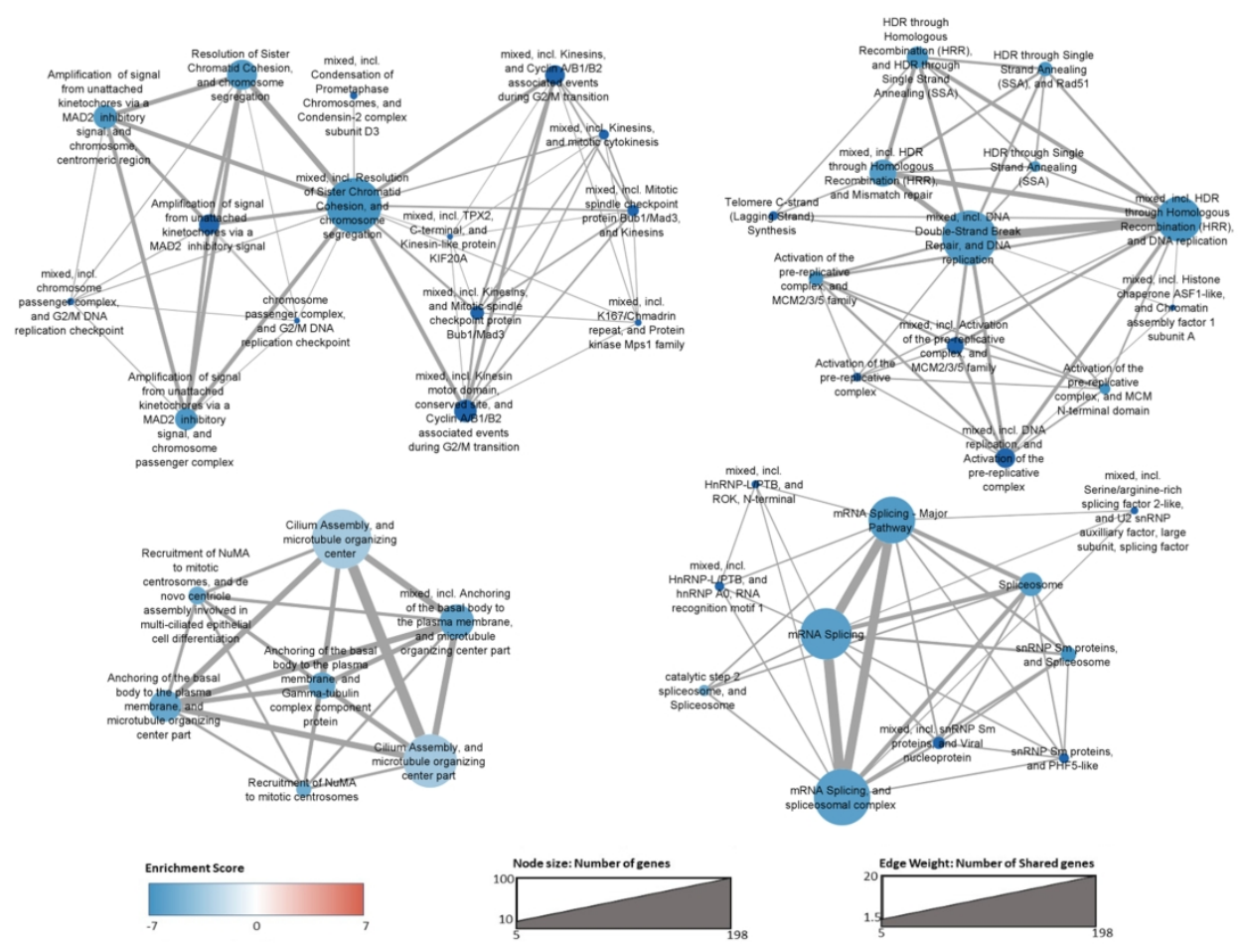

Figure 5. Selected common negatively enriched networks with race2 values during zebrafish development. Each node represents an enriched network, and edge weights represent the number of shared genes. They are colored according to the enrichment score.

$189 \times 144 \mathrm{~mm}(300 \times 300 \mathrm{DPI})$ 


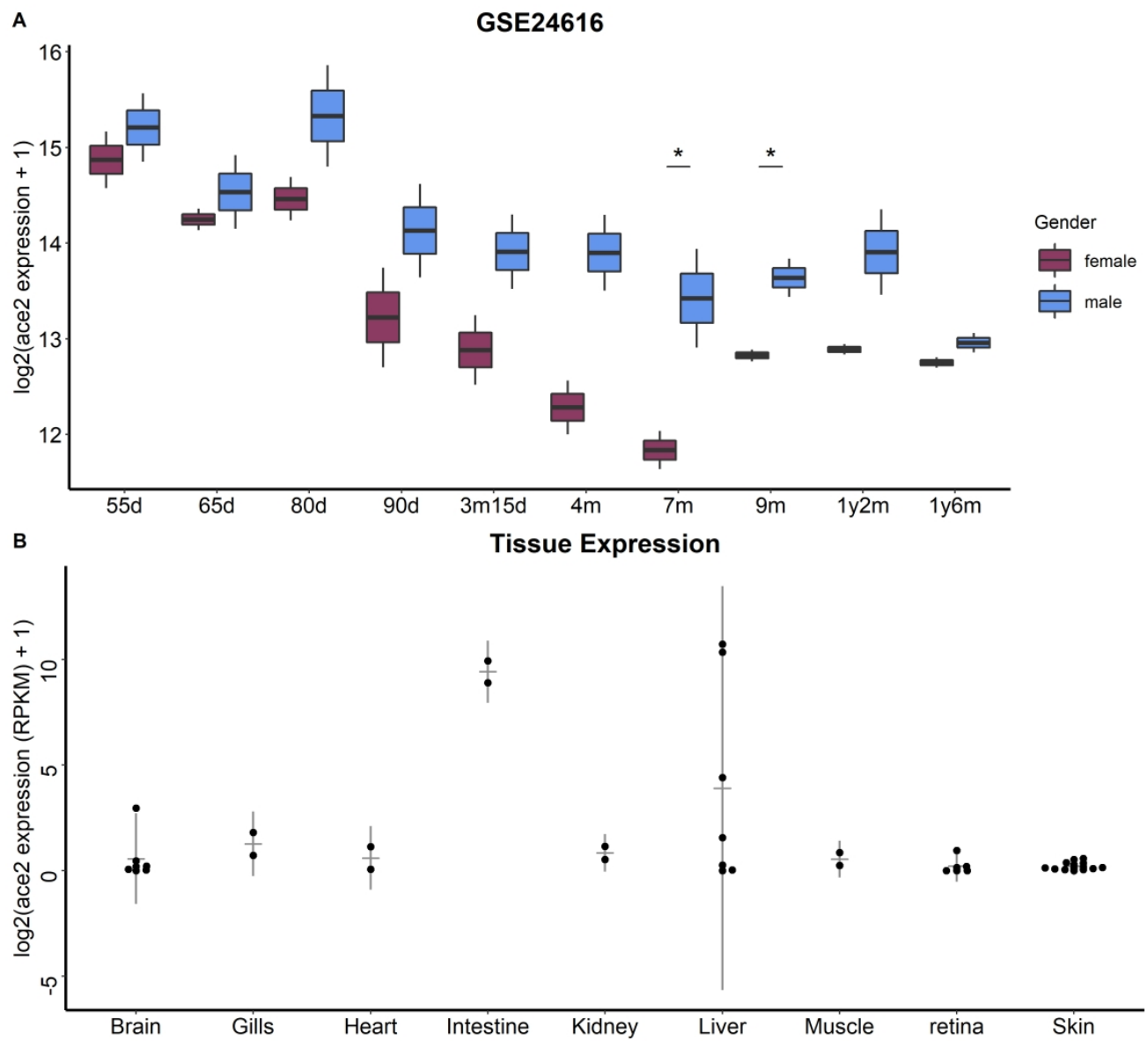

Figure 6. Sexual dimorphic expression pattern in adulthood based on GSE24616 (Simple effect analysis following Two-Way ANOVA results were represented. *, p-value $<0.05)($ A). Tissue-specific expression of ace2 $(\log 2($ RPKM+1)) in the intestines (731.1) and liver (432.8) and the relatively low expression in the gills (1.57), brain (1.08), kidney (0.83), heart (0.62), and muscle (0.49) in the six-month-old zebrafish cohort (B).

$279 \times 254 \mathrm{~mm}(300 \times 300 \mathrm{DPI})$ 
A

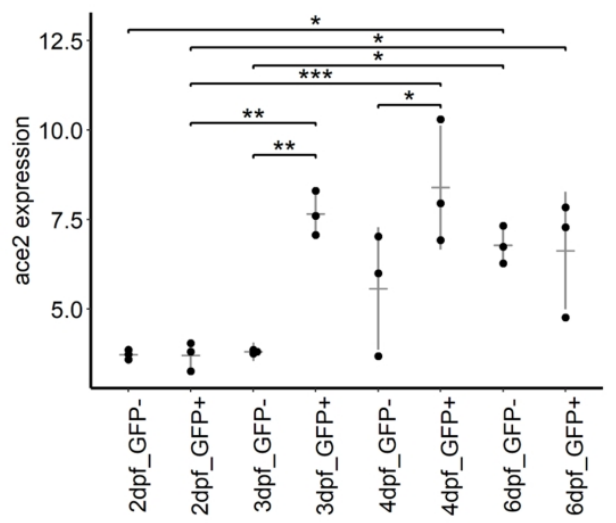

B

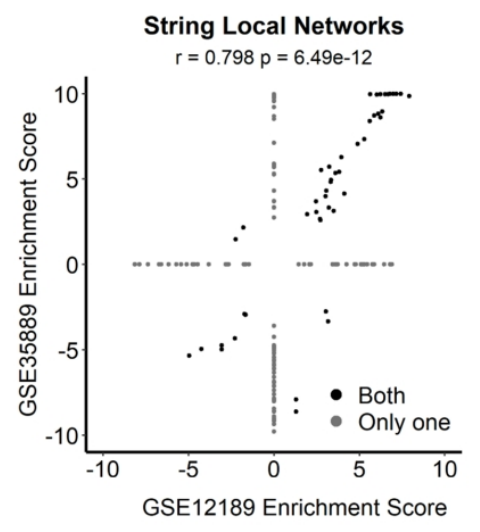

C

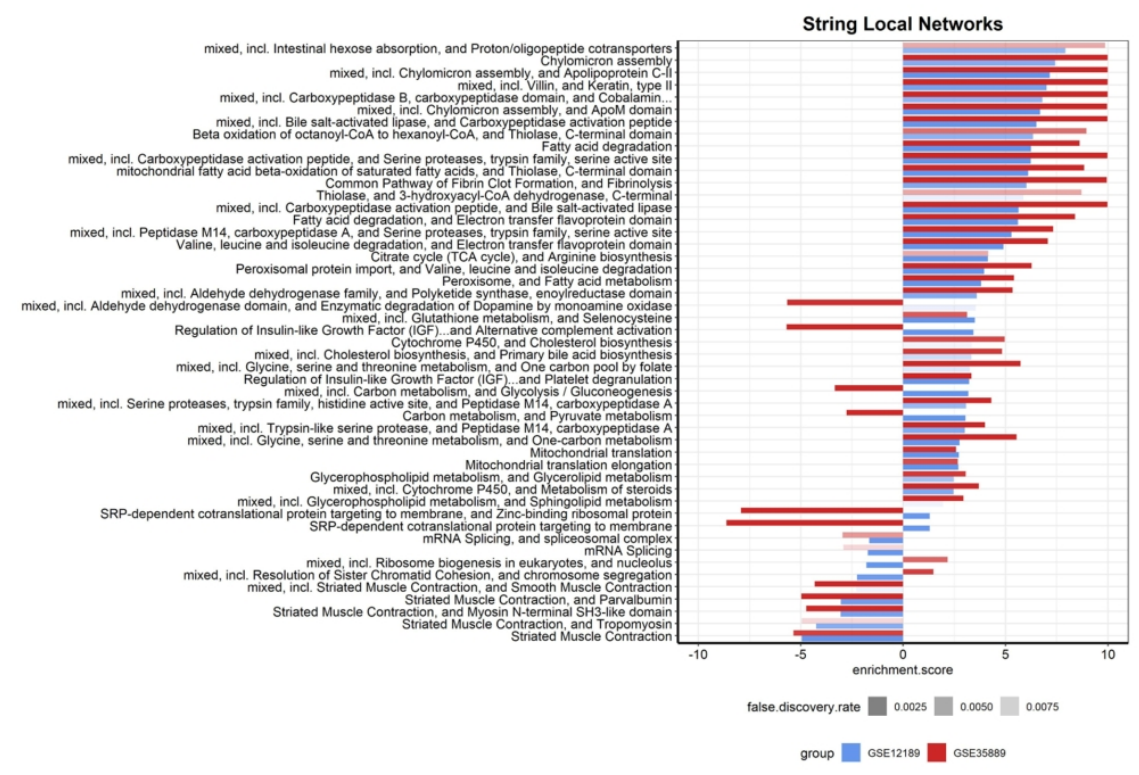

Figure 7. ace2 expression from GSE12189 where GFP+ and GFP- refer to cells in and out of digestive tract, respectively (A, Limma results were represented. $*$, adj. p-value $<0.05$; $* *$, adj. p-value $<0.01$; $* * *$, adj. p-value < 0.001; ****, adj. p-value < 0.0001). Correlation between the significantly modulated STRING local networks obtained using race2 values in GSE12189 and GSE35889 intestine-specific datasets (B). Bar plots of significant STRING local network enrichment scores for GSE12189 and GSE35889 (C).

$202 \times 221 \mathrm{~mm}(300 \times 300 \mathrm{DPI})$ 

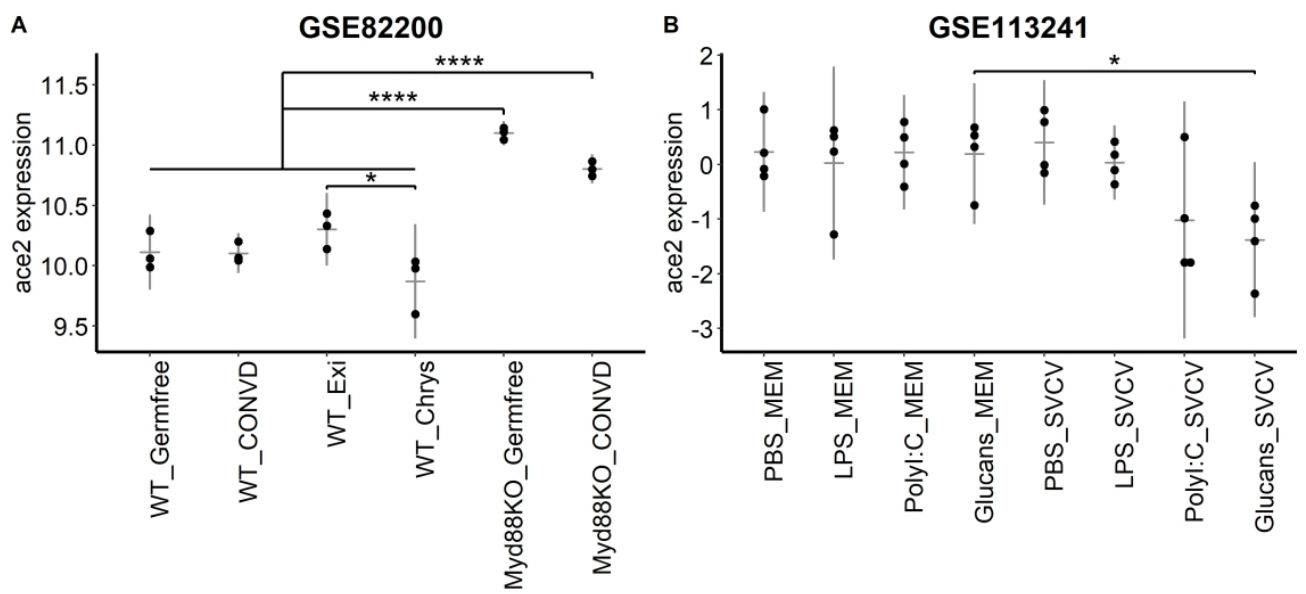

Figure 8. ace2 expression during immune response in myd88 knock-out (Myd88KO) model with bacterial colonization (Conventionalization (CONVD), Exiguobacterium (Exi) and Chryseobacterium (Chrys)) (Tukey HSD corrected One-way ANOVA results were represented. *, adj. p-value $<0.05$; $* * * *$, adj. p-value < $0.0001)(A)$; in viral infection (SVCV: Spring Viraemia Carp Virus) after pre-treatment with the viral medium (MEM), $\beta$-glucans, lipopolysaccharide (LPS), or Polyinosinic:polycytidylic acid (PolyI:C) (Simple effect analysis following Two-Way ANOVA results were represented. *; p-value <0.05) (B).

$$
279 \times 127 \mathrm{~mm}(300 \times 300 \text { DPI) }
$$


A

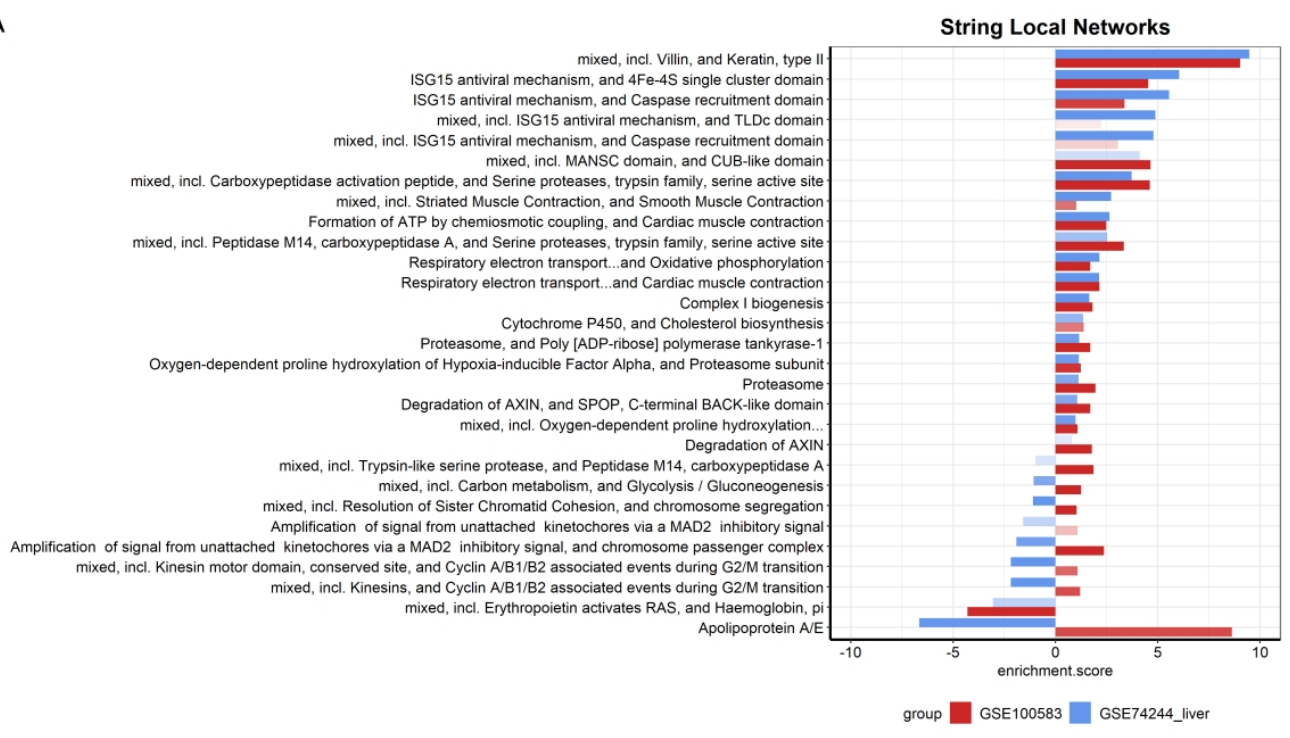

B

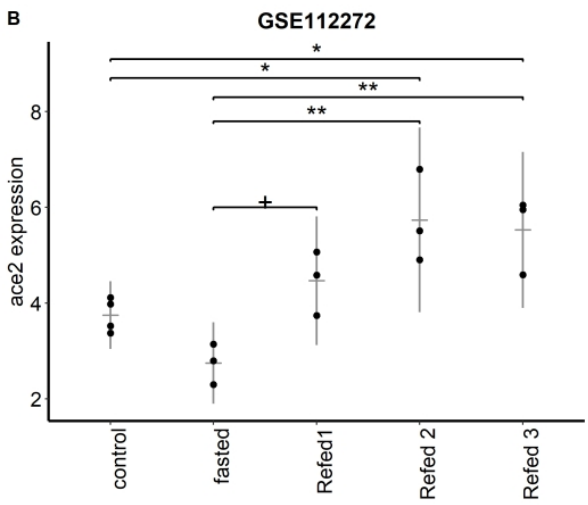

C

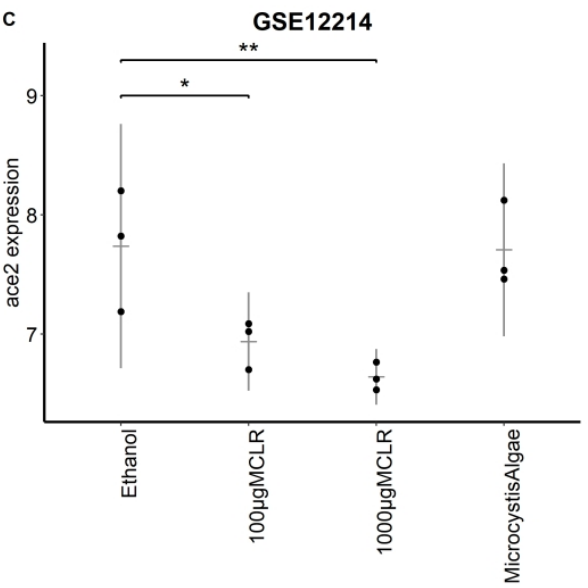

Figure 9. Bar plots of significant STRING local network enrichment scores for GSE74244 and GSE100583 liver datasets (A); ace 2 expression in zebrafish livers during fasting and refed conditions (B); in microcystinLR (MCLR) exposure $(*, p$-value $<0.05 ; * *$, p-value $<0.01)(C)$.

$338 \times 355 \mathrm{~mm}(300 \times 300$ DPI) 